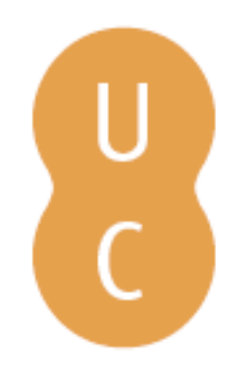

\title{
pompalina
}

\section{Estratégias, patronos e favores em Colóquios dos Simples de Garcia de Orta}

Autor(es): $\quad$ Carvalho, Teresa Nobre de

Publicado por: UA Editora - Universidade de Aveiro; Imprensa da Universidade de

URL

persistente: URI:http://hdl.handle.net/10316.2/35690

DOI: $\quad$ DOI:http://dx.doi.org/10.14195/978-989-26-0941-6_4

Accessed : $\quad$ 26-Apr-2023 03:25:20

A navegação consulta e descarregamento dos títulos inseridos nas Bibliotecas Digitais UC Digitalis, UC Pombalina e UC Impactum, pressupõem a aceitação plena e sem reservas dos Termos e Condições de Uso destas Bibliotecas Digitais, disponíveis em https://digitalis.uc.pt/pt-pt/termos.

Conforme exposto nos referidos Termos e Condições de Uso, o descarregamento de títulos de acesso restrito requer uma licença válida de autorização devendo o utilizador aceder ao(s) documento(s) a partir de um endereço de IP da instituição detentora da supramencionada licença.

Ao utilizador é apenas permitido o descarregamento para uso pessoal, pelo que o emprego do(s) título(s) descarregado(s) para outro fim, designadamente comercial, carece de autorização do respetivo autor ou editor da obra.

Na medida em que todas as obras da UC Digitalis se encontram protegidas pelo Código do Direito de Autor e Direitos Conexos e demais legislação aplicável, toda a cópia, parcial ou total, deste documento, nos casos em que é legalmente admitida, deverá conter ou fazer-se acompanhar por este aviso.

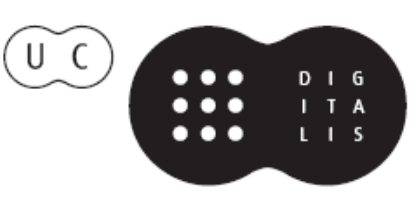




\section{HUMANISMO E CIÊNCIA Antiguidade e Renascimento}

António Manuel Lopes Andrade

Carlos de Miguel Mora

João Manuel Nunes Torrão
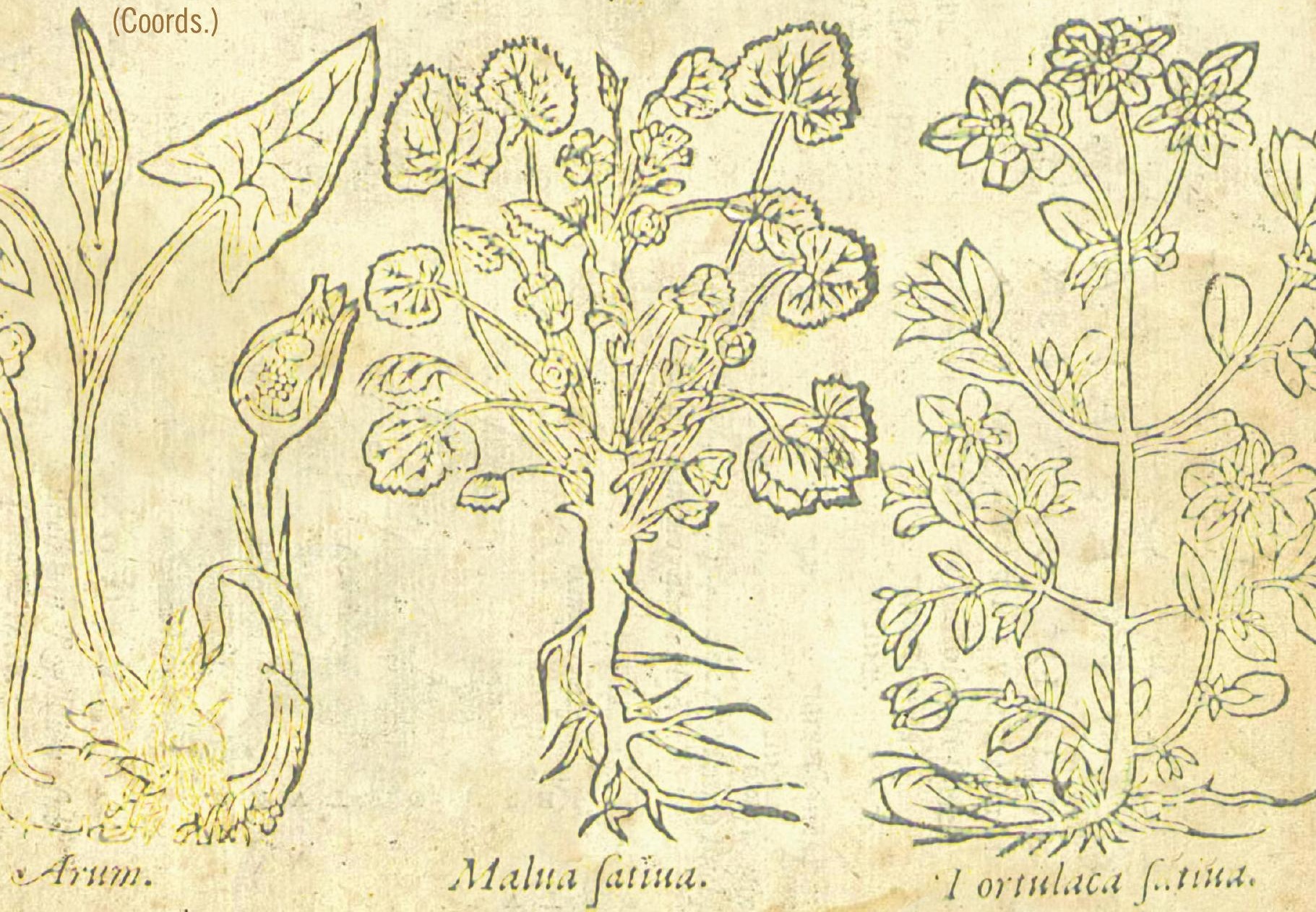

Aveiro I Coimbra I São Paulo 2015

UA Editora - Universidade de Aveiro I Imprensa da Universidade de Coimbra I Annablume 
Este volume resulta de várias iniciativas desenvolvidas no âmbito do projecto de I\&D "Dioscórides e o Humanismo Português: os Comentários de Amato Lusitano" (http://amatolusitano.web.ua.pt), recoIhendo contribuições de mais de duas dezenas de colaboradores, tanto de membros da equipa como de outros investigadores nacionais e estrangeiros. Entre os eventos que estiveram na origem deste livro destacam-se as três edições do Ciclo de Conferências promovido pelo projecto, realizadas entre 2010 e 2013, e sobretudo o Colóquio Internacional "Dioscórides e o Humanismo Português: os Comentários de Amato Lusitano", que decorreu no Departamento de Línguas e Culturas da Universidade de Aveiro, nos dias 21 e 22 de Novembro de 2013.

0 objectivo principal do projecto é a edição e tradução para português dos dois livros que Amato Lusitano dedicou ao comentário do tratado grego De materia medica de Dioscórides, ou seja, o Index Dioscoridis (Antuérpia, 1536) e as In Dioscoridlis Anazarbei de medica materia libros quinque... enarrationes (Veneza, 1553), estando contemplada, também, a tradução de mais duas obras directamente correlacionadas com os livros do médico português: a montante, a do próprio tratado grego de Dioscórides; a jusante, a do livro intitulado Apologia adversus Amathum Lusitanum (Veneza, 1558) de Pietro Andrea Mattioli.

OBRA PUBLICADA COM A COORDENAÇÃO

CIENTÍFICA DE:

Centro de Línguas, Literaturas e Culturas da Universidade de Aveiro

Centro de Estudos Clássicos e Humanísticos da Universidade de Coimbra

Cátedra de Estudos Sefarditas "Alberto

Benveniste" da Faculdade de Letras da Universidade de Lisboa 


\section{HUMANISMO E CIÊNCIA}

\section{Antiguidade e Renascimento}

ANTÓNIO MANUEL LOPES ANDRADE

CARLOS DE MIGUEL MORA

JOÃO MANUEL NUNES TORRÃO

(COORDS.)

AVEIRO • COIMBRA • SÃO PAULO

2015

UA EDITORA • UNIVERSIDADE DE AVEIRO

IMPRENSA DA UNIVERSIDADE DE COIMBRA

ANNABLUME 


\section{HUMANISMO E CIÊNCIA: Antiguidade e Renascimento}

\author{
EDIÇÃO

UA EDITORA • UNIVERSIDADE DE AVEIRO
IMPRENSA DA UNIVERSIDADE DE COIMBRA
ANNABLUME

ORGANIZAÇÃO E COORDENAÇÃO EDITORIAL ANTÓNIO MANUEL LOPES ANDRADE

CARLOS DE MIGUEL MORA

JOÃO MANUEL NUNES TORRÃO

\author{
DESIGN DA CAPA \\ MEIOKILO DESIGN STUDIO
}

DESIGN

CARLOS COSTA

IMPRESSÃO E ACABAMENTO

SERSILITO • MAIA

ISBN

UA • 978-972-789-434-5

IUC • 978-989-26-0940-9

\section{ISBN DIGITAL}

UA • 978-972-789-435-2

IUC • 978-989-26-0941-6

DOI

http://dx.doi.org/10.14195/ 978-989-26-0941-6

DEPÓSITO LEGAL 368241/13

TIRAGEM 500 Exemplares

(C) 2015

UA EDITORA • UNIVERSIDADE DE AVEIRO IMPRENSA DA UNIVERSIDADE DE COIMBRA

ANNABLUME

\section{COMISSÃO CIENTÍFICA}

António Manuel Lopes Andrade

Carlos de Miguel Mora

Delfim Ferreira Leão

Henrique Leitão

João Manuel Nunes Torrão

Maria de Fátima Reis

Maria do Céu Zambujo Fialho

Miguel Ángel González Manjarrés

\section{TEXTOS}

Adelino Cardoso

Ana Leonor Pereira

Ana Margarida Borges

António Guimarães Pinto

António Maria Martins Melo

Bernardo Mota

Carlos A. Martins de Jesus

Carlos de Miguel Mora

Cristina Santos Pinheiro

Donald Beecher

Emília Oliveira

Isabel Malaquias

James W. Nelson Novoa

Joana Mestre Costa

João Manuel Nunes Torrão

João Rui Pita

Jorge Paiva

José Sílvio Moreira Fernandes

Maria de Fátima Silva

Miguel Ángel González Manjarrés

Rui Manuel Loureiro

Telmo Corujo dos Reis

Teresa Nobre de Carvalho

Vinicije B. Lupis

Virgínia Soares Pereira 


\section{HUMANISMO E CIÊNCIA}

\section{Antiguidade e Renascimento}

ANTÓNIO MANUEL LOPES ANDRADE

CARLOS DE MIGUEL MORA

JOÃO MANUEL NUNES TORRÃO

(COORDS.)

AVEIRO • COIMBRA • SÃO PAULO

2015

UA EDITORA • UNIVERSIDADE DE AVEIRO

IMPRENSA DA UNIVERSIDADE DE COIMBRA

ANNABLUME 
OBRA PUBLICADA

COM A COORDENAÇÃO

CIENTÍFICA DE:

CENTRO DE LÍNGUAS,

LITERATURAS E CULTURAS DA

UNIVERSIDADE DE AVEIRO

CENTRO DE ESTUDOS

CLÁSSICOS E HUMANÍSTICOS DA

UNIVERSIDADE DE COIMBRA

CÁTEDRA DE ESTUDOS SEFARDITAS

"ALBERTO BENVENISTE"

DA FACULDADE DE LETRAS DA

UNIVERSIDADE DE LISBOA 


\section{SUMÁRIO}

PREFÁCIO

1.1 "Teofrasto, Tratado das plantas. No alvor de uma nova ciência" 13

Maria de Fátima Silva

1.2 "Francisco de Melo e os fragmentos de teoria óptica de Pierre Brissot" 21 Bernardo Mota

1.3 "Algumas reflexões sobre as pedras preciosas nos Colóquios dos simples de Garcia de Orta" 37 Rui Manuel Loureiro

1.4 "Estratégias, patronos e favores em Colóquios dos Simples de Garcia de Orta" 63 Teresa Nobre de Carvalho

1.5 "As plantas na obra poética de Camões (épica e lírica)" 95 Jorge Paiva

1.6 "Nicolás Monardes, John Frampton and the Medical Wonders of the New World" .141 Donald Beecher

1.7 "Literatura e Medicina: alguns textos de Justo Lípsio e de dois doutores Luís Nunes" 161 António Guimarães Pinto

1.8 "Ontologias e idiossincrasias dos Amantes, à luz da Archipathologia de Filipe Montalto" ...... 211 Joana Mestre Costa \& Adelino Cardoso

1.9 "Gabriel da Fonseca. A New Christian doctor in Bernini's Rome". .227 James W. Nelson Novoa 


\section{2) DIOSCÓRIDES E O HUMANISMO PORTUGUÊS: OS COMENTÁRIOS DE AMATO LUSITANO}

2.1 "Léxico científico português nos Comentários de Amato: antecedentes e receção"

Ana Margarida Borges

2.2 "Usos medicinais das plantas, em Amato Lusitano: o bálsamo"

António Maria Martins Melo

2.3 "Amato Lusitano e a importância da ilustração botânica no século xVI.

Em torno das edições lionesas das Enarrationes (1558)"

Carlos A. Martins de Jesus

2.4 "Sobre la identificación entre ébano y guayaco en una entrada

del Index Dioscoridis de Amato Lusitano".

Carlos de Miguel Mora

2.5 "Os partos distócicos em Amato Lusitano e em Rodrigo de Castro:

fontes, doutrinas e terapias greco-romanas"

\section{Cristina Santos Pinheiro}

2.6 "Do carvalho ao castanheiro: usos e propriedades medicinais

de fagáceas nas Enarrationes de Amato Lusitano".

Emília Oliveira

2.7 "O mundo mineral nos Comentários a Dioscórides de Amato Lusitano".

Isabel Malaquias \& Virgínia Soares Pereira

2.8 "Alguns comentários de Amato: entre a estranheza e a realidade"

João Manuel Nunes Torrão

2.9 "Caracterização e usos terapêuticos de produtos de origem marinha

nos Comentários de Amato Lusitano a Dioscórides"

José Sílvio Moreira Fernandes

2.10 "La mandrágora de Amato Lusitano: edición, traducción y anotación"

Miguel Ángel González Manjarrés

2.11 "O vinho e os vinhos - usos e virtudes de um dom dos deuses

nas Enarrationes de Amato Lusitano"

Telmo Corujo dos Reis

2.12 "Amatus Lusitanus e Didaco Pirro: due ebrei portoghesi

e cerchia umanistica di Dubrovnik" 481

Vinicije B. Lupis

2.13 "Estudos contemporâneos sobre Amato Lusitano". 513

João Rui Pita \& Ana Leonor Pereira 


\title{
Estratégias, patronos e favores em Colóquios dos Simples de Garcia de Orta
}

\author{
TERESA NOBRE DE CARVALHO ${ }^{1}$
}

\section{RESUMO:}

Em 1563, foi publicada em Goa, uma obra notável. Editada na tipografia de Endem, Colóquios dos Simples e Drogas e Coisas Medicinais da Índia, da autoria do médico português Garcia de Orta (c.1500-1568), divulgou no Ocidente um saber renovado sobre os recursos naturais da Ásia.

Numa altura em que os sábios europeus ainda hesitavam em pôr em causa os conteúdos científicos transmitidos pelos tratados médico-botânicos herdados da Antiguidade, Orta aventurouse a enfrentar a tradição. Socorrendo-se da sua erudição e apoiando-se na autoridade que the conferia a sua ampla experiência clínica no Oriente, o médico ousou corrigir, actualizar e rever o saber sobre a matéria médica asiática então em circulação. Para garantir o crédito e aplauso da comunidade erudita, o seu arrojado plano aconselhava um suporte institucional sólido.

Ao longo deste ensaio percorremos os bastidores de Colóquios dos Simples em busca dos seus patronos. Propusemo-nos explorar os contextos em que o tratado surgiu, reconhecer as principais personagens implicadas na sua construção e esclarecer as motivações do médico na sua publicação.

\section{PALAVRAS CHAVE:}

Garcia de Orta; Colóquios dos Simples; Martim Afonso de Sousa; Patronos.

\section{ABSTRACT:}

In 1563, a remarkable work was published at the Endem's print-shop, in Goa: Colóquios dos Simples e Drogas e Coisas Medicinais da Índia. Written by the Portuguese physician Garcia de Orta (c. 15001568), this volume revealed a renewed knowledge about the Asian natural resources.

At a time when the European scholars still hesitate to question the scientific content of the Ancient treatises, Orta dared to question tradition. Relying on the authority that his extensive clinical experience in the Orient gave him, Orta took the risk to correct, update and revise the knowledge about the Asian resources in circulation. But to ensure the credit and applause of the erudite community to his work he needed institutional support.

Throughout this article we discover the Colloquies backstage searching for Orta's patrons. We explore the contexts in which the book emerged, recognizing the main characters involved in its construction.

\section{KEYWORDS:}

Garcia de Orta; Colóquios dos Simples [Colloquies on the Simples]; Martim Afonso de Sousa; Patrons.

1 Doutorada em História e Filosofia das Ciências pela Universidade de Lisboa-CIUHCT - Faculdade de Ciências da Universidade de Lisboa: tercarvalho@gmail.com. 
Quando buscamos em Colóquios dos Simples e Drogas e Coisas Medicinais da Índia (Goa, 1563) o nome do seu patrocinador, somos confrontados com um aparente silêncio. $\mathrm{O}$ autor, Garcia de Orta (c. 1500-1568), apesar de no seu tratado nos ter lançado algumas pistas, deixou-nos várias dúvidas sobre este ponto.

Nesta obra, escrita em diálogo, o saber sobre os recursos naturais asiáticos foi integralmente revisto, actualizado e, sempre que necessário, corrigido. ${ }^{2}$ Ao longo do seu compêndio, Garcia de Orta revelou aos seus leitores a sua inquestionável competência técnica, alicerçada numa escrupulosa formação científica adquirida, na década de 1520, nas universidades de Salamanca e Alcalá de Henares. Mas o saber de Orta não se limitava aos conhecimentos angariados durante os seus estudos médicos. Apesar da sua prolongada permanência no Oriente (1534-1568), o físico, referindo numerosas obras médicas entretanto editadas na Europa, atestou uma cuidada e permanente actualização científica. ${ }^{3}$ Alardeando uma vasta experiência clínica adquirida nos hospitais do Oriente e um profundo conhecimento das drogas e especiarias asiáticas, não se coibiu de manifestar a sua autoridade relativamente a estes valiosos recursos.

Se é inquestionável a relevância dos novos saberes que o médico adquirira ao longo da sua vivência asiática, continuam por esclarecer numerosos aspectos relativos ao patrocínio desta obra.

Ao longo deste ensaio percorremos os bastidores de Colóquios dos Simples. Propusemo-nos explorar os contextos em que o tratado surgiu, reconhecer as principais personagens implicadas na sua construção e esclarecer as motivações do médico na sua publicação. O que este artigo propôe é uma aproximação às origens deste tratado.

2 Ao longo de 59 capítulos, o autor descreveu as conversas entre dois médicos ibéricos - Orta e Ruano - que esgrimiram argumentos textuais e testemunharam experiências sobre os recursos naturais asiáticos. Em relação a cada produto, Garcia de Orta apresentou aos seus leitores uma renovada e autorizada descrição.

3 Sobre a biblioteca de Orta ver: Conde de Ficalmo, Garcia de Orta e o seu tempo. Lisboa, Imprensa Nacional, 1886, pp. 280-298; Rui Manuel Loureiro, "Garcia de Orta e os Colóquios dos Simples: Observações de um viajante sedentário", in Anabela Mendes e Gabriela Fracoso (org.), Garcia de Horta e Alexandre von Humboldt. Errâncias, Investigações e Diálogos entre Culturas. Lisboa, Universidade Católica Editora, 2008, pp. 135-145; Teresa Nobre de CARVALHo, O mundo natural asiático aos olhos do Ocidente. Contribuição dos textos ibéricos quinhentistas para a construção de uma nova consciência europeia sobre a Ásia. Lisboa, UL, 2012, pp. 225-313 (dissertação de doutoramento - texto policopiado). 


\section{CONTEXTO DA OBRA}

"O poder não é uma coisa mas sim um processo e o mecenas é alguém que pode fazer coisas pelo seu cliente. Um mecenas tem poder, na medida em que o pode fazer circular e ser produtivo. Por consequência, um mecenas moderno dos primeiros tempos era frequentemente um agente, um trait d'union entre o cliente e uma fonte de mais poder [...]."4

Buscando em Colóquios dos Simples as forças que sustentaram a edição, tentámos reconstituir os contextos em que o médico se movia. Procurámos, por isso, o círculo de influentes que cruzava. Apesar de, ao longo do texto, Orta descrever variadas situações que têm como protagonistas governantes e prelados destacados no Oriente, parece-nos que as circunstâncias próximas da data da edição são as mais esclarecedoras sobre a oportunidade da publicação. ${ }^{5}$

Vale a pena abrir aqui um parêntesis para salientar que a revelação, a uma escala global, de novidades desta importância estava destinada aos "grandes" do Reino. Pietro Andrea Mattioli (1501-1577), um dos mais destacados comentadores de Dioscórides, na sua edição de 1544, havia exortado o rei de Portugal, D. João III, o Piedoso, (r.1521-1557) a chamar a si esta responsabilidade. O médico prometia "imortalidade" ao nome do soberano, caso este tomasse a seu cargo o patrocínio desta tarefa que traria tão grande bem a toda a humanidade. ${ }^{6}$

Até ao momento não conseguimos reunir elementos que nos permitam comprovar o empenhamento do soberano na edição desta obra. No entanto, e porque nos parece plausível a implicação de D. João III e dos homens da sua confiança na génese de um trabalho desta natureza, acalentamos a esperança de vir a conseguir reunir os dados que demonstrem a aspiração do rei em publicar um tratado científico sobre esta temática, com impacto à escala do império e do mundo. ${ }^{7}$

4 Mario BıAGıOLI, Galileo cortesão. Lisboa, Porto Editora, 2003, p. 22.

5 Ao longo da obra, Orta narrou episódios que tinham como protagonistas, entre outros, Nuno da Cunha (g.1529-1538), Martim Afonso de Sousa (g.1542-1545), D. João de Castro (g.1545-1548), D. Pedro de Mascarenhas (g.1554-1555), D. Constantino de Bragança (g.1558-1561), para além de religiosos, missionários e alguns fidalgos que nomeou mas que não identificou.

6 Sobre esta afirmação de MATTIOLI ver, por exemplo, a versão francesa de Commentaires à Dioscoride. Lião, Rouille, 1572, Cap. 12, p. 40: "Et vous Messieurs les Médecins du Portugal, si la Médecine vous est en recommandation, si voulez enrichir votre profession, exalter $\&$ faire grand votre nom, si charité a lieu en votre endroit, si vous avez ce naturel instinct $\&$ désir d'aider le genre humain, prenez cette charge: car si le Prince est par vous averti que ce lui sera un grand moyen d'immortaliser son nom, \& qu'il sera cause d'un grandissime bien à tout le monde...".

7 Sobre o desenvolvimento das ciências e técnicas em Portugal na primeira metade de Quinhentos, há uma vasta bibliografia. Nas mais diversas áreas científicas surgiram portugueses que se destacaram pela profundidade dos seus estudos ou pela inovação dos seus trabalhos. Numa lista que permanecerá sempre incompleta destacam-se todos quantos desempenharam funções em torno do monarca e das instituições de saber dele dependentes. Aos tratados dos físicos, matemáticos, astrónomos, cosmógrafos e cartógrafos teremos que aliar os relatos e saberes de boticários, cirurgiões, jardineiros, artesãos e outros técnicos que, com a sua experiência, resolveram questões pragmáticas relativas à medicina, à agricultura, 
Não devemos, assim, desligar a edição desta obra de um contexto mais alargado no qual se assistiu, à produção e circulação de numerosa informação manuscrita e impressa, de carácter científico e técnico, compulsada e redigida por portugueses ao longo do século XVI. ${ }^{8}$

O empenho dos monarcas ibéricos no desenvolvimento das ciências foi, aliás, amplamente comprovado por investigaçóes do século passado. Pesquisas recentes despertaram um interesse crescente sobre este assunto e têm trazido a lume novas evidências. ${ }^{9}$ Como foi demonstrado, o encontro com novos territórios e realidades diversas obrigou sábios, funcionários régios e artesãos a repensar muitos dos métodos e técnicas tradicionais. Para lidar com a novidade, os governantes

à náutica, à construção naval, à arquitectura militar ou à balística. Sobre a inovação técnico-científica ocorrida em Portugal na primeira metade de Quinhentos, vide, entre outros: Reijer HooYKAAS, "Science in manueline style. The historical context of D. João de Castro's Works", in Armando CoRTESÃo and Luís de Albuqueroue, Obras Completas de D. João de Castro. Coimbra, Academia Internacional da Cultura Portuguesa, 1981, vol. IV, pp. 231-426; Luis de AlbuQueroue, Introdução à história dos descobrimentos. Coimbra, Atlântida, 1962; Francisco Contente Domingues, Os navios do mar oceano. Teoria e empiria na arquitectura naval portuguesa dos séculos XVI exVII. Lisboa, CHUL, 2004; José Mendes FERRÃo, A aventura das plantas e os descobrimentos. Lisboa, Chaves Ferreira, 2005; Henrique LEITÃo, "Um mundo novo e uma nova ciência", in Henrique LEITÃo (ed.), $360^{\circ}$ Ciência Descoberta. Lisboa, Fundação Calouste Gulbenkian, 2013, pp. 15-40. Sobre a importante reforma na universidade portuguesa verificada neste período vide José S. Silva DIAS, A política cultural da época de D. João III. Coimbra, Universidade de Coimbra, 1969, 2 vols.

8 A abundância de tratados, regimentos e descrições de territórios publicada ou colocada em circulação neste período impede-nos, no âmbito deste estudo, de apresentar uma lista exaustiva. Limitamonos, por isso, a título de exemplo, a registar alguns dos textos de autores portugueses editados nas oficinas gráficas de Portugal e do resto da Europa: Gaspar Nicolas, Tratado da Pratica d'Arismetica (Lisboa, 1519); Amato Lusitano, Index Dioscoridis (Antuérpia, 1536); Pedro Nunes, Tratado da Sphera (Lisboa, 1537); António Luís, De re medica opera quae hic sequuntur (Lisboa, 1540); Pedro NunES, De crepusculis liber unus (Lisboa, 1542); Pedro NunEs, De arte atque ratione navigandi, (Coimbra, 1546); AmATo LusitANo, Curationum medicinalium (Florença, 1551); AmATo LusITANo, Enarrationes eruditissimae (Veneza, 1553); António Galvão, Tratado dos descobrimentos (Lisboa, 1563); Garcia Lopes, Comentarii de varia rei medica lectione (Antuérpia, 1564); Pedro Nunes, Petri Nonii Salaciensis Opera, (Basileia, 1566), Pêro Magalhães GÂNDAVo, História da Província de Santa Cruz (Lisboa, 1576); Francisco SANCHES, Quod nihil scitur (Londres, 1581); Gabriel Soares de SouSA, Tratado descritivo do Brasil (Lisboa, 1587) ou João Baptista Lavanha, Regimento Nautico de loão Baptista Lauanha, Cosmographo môr de El Rey Nosso Senhor (Lisboa, 1595).

9 Para além das obras de Luís de PINA, "As ciências na história do Império colonial português (séculos XV-XIX)", Extracto dos tomos dos anos 1937 a 1945 nos Anais da Faculdade de Ciências do Porto. Porto, Imprensa Portuguesa, 1945 e José-Maria LóPEZ-PIÑERo (dir.), Historia de la ciência y de la técnica en la corona de Castilla, Vol. III. Siglos xv y XVII. Salamanca, Junta de Castilla y Léon, Consejeria de Educación y Cultura, 2002, vide também as de David Goodman, Power and Penury: Government, technology and science in Philip II's Spain. Cambridge, Cambridge University Press, 1988; Jorge CaÑIZAREs-EsGuerRa, "Iberian Science in Renaissance: ignored how much longer?", Perspectives on Science 12, n. ${ }^{\circ} 1$ (2004), pp. 86-124; Antonio BARRERA, Experiencing nature. The Spanish American Empire and the Early Scientific Revolution. Austin, University of Texas Press, 2006; Londa SCHIEBINGER and Claudia SWAN, Colonial Botany. Science, Commerce and Politics in Early Modern Europe. Philadelphia, University of Pennsylvania Press, 2007; Daniela BLEICHMAR, Science in the Spanish and Portuguese Empires, 1500-1800. Standford, Standford University Press, 2009; Antonio SÁnChez-MARTínez, "Ciencia ibérica y el mundo Atlántico", Dynamis 31 (2011), pp. 245-269 ou Antonio Sánchez-MARTínez, "La voz de los artesanos en el Renacimiento científico: cosmógrafos y cartógrafos en el preludio de la "nueva filosofía natural", Arbor, CLXXXVI, 743 (Maio-Junho 2010), pp. 449-460. 
portugueses e espanhóis viram-se a braços com dificuldades muito concretas. Para além da necessidade de uma mais correcta localização e demarcação dos limites dos lugares alcançados, da busca de rigor no registo das informaçóes cartográficas, da concepção de instrumentos mais precisos, da criação de métodos mais fidedignos de ajuda à navegação ou da construção de naves cada vez mais adequadas às grandes travessias oceânicas, foi fundamental estabelecer aprofundados recenseamentos dos recursos naturais e pesquisar soluçôes terapêuticas para novos e velhos males. Estes foram alguns dos desafios a que os funcionários régios tiveram que responder e para os quais contaram com o apoio dos monarcas e o assentimento das suas cortes. A recolha de notícias e informaçóes relativas a tão amplos territórios levou à criaçáo, em Lisboa e Sevilha, de instituições de acumulação e gestão de novos saberes assim como à fundação de instituiçóes dedicadas ao ensino das bases científicas e técnicas consideradas fundamentais para possibilitar o domínio de mares e leitura dos céus por parte de pilotos e demais tripulação. ${ }^{10}$

Não nos restam hoje quaisquer dúvidas que apesar de, desde a chegada dos portugueses à Índia, se ter verificado um acentuado interesse na recolha de notícias sobre os recursos naturais asiáticos, como o atestam os relatórios circunstanciados de Duarte Barbosa ou Tomé Pires e como o revela o corpus epistolar enviado do Oriente a D. Manuel I (r.1498-1591), esta prospecção só tomou um cariz mais sistemático durante o reinado de D. João III. ${ }^{11}$ Datam deste período numerosos relatos de funcionários destacados no Oriente que, pela relevância estratégica dos seus conteúdos foram resguardados do olhar púbico. Parece-nos por isso plausível que o soberano estivesse interessado na edição de um tratado que divulgasse informação credível sobre a matéria médica asiática. ${ }^{12}$

10 Sobre estes novos desafios e instituições vide: Barbara MUNDY, The mapping of New Spain: indigenous cartography and the maps of the Relaciones Geograficas. Chicago, Chicago University of Chicago Press, 2000; Maria PorTuONDo, Secret Science. Spanish cosmography and the New World. Chicago, The University of Chicago Press, 2009; Daniela BLeICHMAR, Science in the Spanish and Portuguese empires, 1500-1800, op. cit., pp. 35-56 e 219-232; Henrique LeITÃo (ed.), $360^{\circ}$ Ciência Descoberta, op. cit., pp. 15-40.

11 Banha de Andrade, Novos mundos do Mundo. Panorama da difusão, pela Europa, de notícias dos Descobrimentos geográficos Portugueses. Lisboa, Junta de Investigações do Ultramar, 1972, 2 vols.

12 Sobre esta diversidade de relatórios, cartas e listas redigidos pelos funcionários régios, vide: Adelino Almeida CALADo (ed.), "Livro que trata das cousas da Índia e do Japão", Boletim da Biblioteca da Universidade de Coimbra, Vol. XXIV, pp. 1-138. Sobre o acesso de Orta a esta documentação classificada vide: Rui Manuel LoureIRo, Animais Orientais: Fauna exótica dos descobrimentos. Lagos, Câmara Municipal de Lagos, 2008; IDEM, "Information networks in the Estado da India, a case study: was Garcia de Orta the organizer of the Codex Casanatense 1889?", Anais de História de Além-Mar XIII (2012), pp. 41-72. Teresa Nobre de CARVALHo, "Invisible travelers and virtual tracks: knowledge construction in Colóquios dos Simples e Drogas da India of Garcia de Orta (Goa, 1563)", in Antoni Roca-Rosell (ed.), Proceedings of the 4th ESHS Conference, Barcelona, 2010, pp. 288-293; Teresa Nobre de CARVALHO, O mundo natural asiático aos olhos do Ocidente, op. cit., pp. 271-313. 
O desaparecimento do monarca em 1557, a ausência, no Oriente, de oficinas tipográficas capazes de levar a cabo táo difícil empreitada ${ }^{13}$ e a constante actualização e validaçáo de informes que uma obra desta natureza implicava afiguram-se-nos ser alguns dos factores que estorvaram a publicação de tal obra durante a vigência do reinado do Piedoso. A edição do tratado viu-se assim adiada para um momento mais oportuno, tendo surgido apenas em 1563, em Goa, na capital do Estado da Índia, com o selo institucional do recém-chegado Vice-Rei, D. Francisco Coutinho (g. 1561-1564).

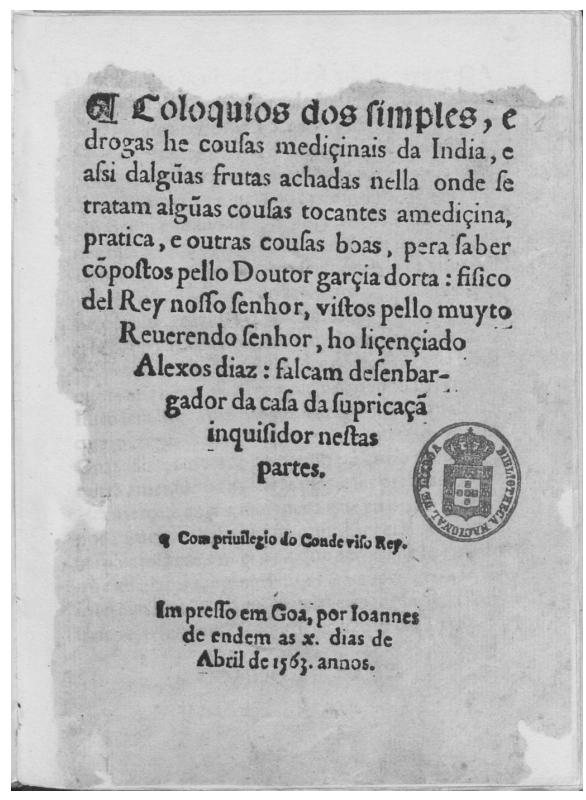

Figura 1 - Na portada de Colóquios dos Simples é bem evidente o apoio institucional que os poderes, político e religioso, deram à obra. Para além do assentimento manifestado pelo licenciado Aleixo Dias Falcão, "inquisidor nestas partes", o Vice-Rei da Índia, o Conde de Redondo assegurou protecção à obra. (Cortesia da Biblioteca Nacional de Portugal)

13 Sobre a instalação das oficinas tipográficas em Goa vide: António ANSELMo, Bibliografia das obras impressas em Portugal no século xvı. Lisboa, Biblioteca Nacional, 1977, [1926], p. 151; Charles R. Boxer, A tentative check-list of Indo-Portuguese imprints. Paris, Centro Cultural Português, 1975, pp. 567-599; H. SCholdberG, Bibliography of Goa and the Portuguese India. New Delhi, 1982, pp. 210-211; Manuel Cadafaz de Matos, "Humanismo e evangelização no Oriente no século xvI", Revista ICALP, n. ${ }^{\circ}$ 7-8, 1987. pp. 41-72; Teresa Nobre de CARVAlHo, O mundo natural da Ásia aos olhos do Ocidente, op. cit., pp. 99-155; Teresa Nobre de CARvalho, "Os enigmas de uma edição goesa: Colóquios dos Simples de Garcia de Orta", in H. Leitão; L. GiURGevitch; T. N. de Carvalho (eds.), O livro científico lido de perto. Lisboa, BNP, 2015 (aceite para publicação). 


\section{UMA OBRA OPORTUNA}

Perante a falta de dados inequívocos sobre o autor da encomenda de Colóquios dos Simples, voltámo-nos assim para a análise dos textos preliminares do tratado. Procurando captar a atenção e a benevolência dos leitores, este conjunto de textos assentou levar ao conhecimento público um saber classificado, até então mantido no âmbito privado. ${ }^{14}$ Integrando o conhecimento relativo aos recursos naturais asiáticos no discurso político da Goa quinhentista, este conjunto de cartas, odes e sonetos, destacou a importância do novo saber veiculado por Orta. ${ }^{15}$

Neste caderno, para além da página de título, onde destacamos a autorização do licenciado Aleixo Dias Falcão, “desenbargador da Casa da Supricaçam, Inquisidor nestas partes”, o volume de Garcia de Orta apresenta: o privilégio do "Conde Viso Rey”, a dedicatória de Garcia de Orta "ao muy ilustre Senhor Martim Afonso de Sousa", um poema "do autor falando co ho seu libro", uma ode de Camóes ao Conde do Redondo e uma carta dirigida pelo "liçenciado Dimas Bosque ao leitor". ${ }^{16}$ Parece-nos interessante realçar desde já que, neste conjunto de escritos, apenas os destinados a Martim Afonso de Sousa (1500-1570) foram da autoria de Orta. Pela relevância que reconhecemos a este facto, detalharemos este aspecto mais à frente.

Sendo D. Francisco Coutinho, 3. ${ }^{\circ}$ Conde de Redondo, o Vice-Rei da Índia em exercício à data da publicação do tratado, não nos surpreende o destaque que este político alcançou nos paratextos. ${ }^{17}$ Se a sua posição central na cena política do Estado da Índia tornava desejável o seu apoio à edição, a relevância estratégica do tema em apreço tornou imprescindível a sua protecção ao autor e aos conteúdos.

Cedendo informações novas sobre as regiōes de origem, as rotas de distribuição, os mercados, a utilidade terapêutica e o valor comercial dos principais recursos naturais do Oriente, Colóquios

14 Sobre o controlo da informação no âmbito imperial há uma ampla bibliografia: Peter BURKE, A social history of knowledge. From Gutemberg to Diderot. Cambridge, Polity Press, 2008, pp. 116-148; David Goodman, Power and Penury..., op. cit., pp. 50-87.

15 Sobre os paratextos de Colóquios dos Simples vide: Rogério Manuel PuGA, "Os elementos paratextuais dos Colóquios de Garcia de Orta", in Anabela Mendes e Gabriela Fragoso (org.), Garcia de Horta e Alexandre von Humboldt. op. cit. pp. 119-134 e Teresa Nobre de CARVALHO, O mundo natural asiático aos olhos do Ocidente, op. cit., pp. 122-138.

16 Garcia de ORTA, Colóquios dos Simples e Drogas da Índia, Edição fac-similada da dirigida e anotada pelo Conde de FICALHo. Lisboa, Imprensa Nacional, 1987 [1891], vol. 1, pp. 3-11. No âmbito deste ensaio recorremos a esta edição que passamos a referir de forma abreviada.

17 Referimo-nos à Ode que Luís de Camões dirigiu ao Vice-Rei. Reveladora de uma proximidade entre o poeta e o médico, esta foi a primeira poesia impressa de Camões. Para o poeta, os grandes feitos bélicos eram tão valiosos como o apoio ao avanço do conhecimento. O mesmo empenho de Camões relativamente à divulgação de saberes sobre novos espaços sob domínio português verificou-se na obra de Pêro Magalhães GÂNDAvo, História da Província de Santa Cruz. Lisboa, 1576, na qual também dedicou um poema a um ilustre fidalgo. Vide: Teófilo BRAGA, A primeira poesia impressa de Luis de Camões. Lisboa, Adolfo Modesto, 1867 e Teresa Nobre de CARVALHO, O mundo natural asiático aos olhos do Ocidente, op. cit., pp. 122-138. 
dos Simples destacou-se no panorama científico de Quinhentos. ${ }^{18} \mathrm{O}$ nome daquele que conferiu protecção jurídica a obra tão inovadora ficou-lhe ligado de forma indelével. Independentemente da relevância política dos feitos que D. Francisco Coutinho realizou ao longo da sua governação, o seu nome seria para sempre lembrado pelo patrocínio que cedeu a este volume. Apoiar, de forma activa, um tratado científico desta natureza inscreveu D. Francisco Coutinho naquele grupo de homens de corte capazes de grandes feitos, na guerra como nas letras. O nome de Orta, por seu turno, ao ser identificado com o do médico do Vice-Rei, tornou-se, de imediato, numa referência credível para os leitores da sua obra.

Convém salientar que quando o Conde de Redondo entrou em funçóes, a obra de Orta já estava adiantada uma vez que a assinatura do Privilégio data de 5 de Novembro de 1562. Do seu texto salientamos o parágrafo inicial:

O Conde Viso-Rey da India, etc., faço saber a quantos este meu alvará virem, que o doutor Garcia d'Orta me inviou dizer que elle tinha feito hum livro pera enpremir das mézinhas e fruitas da India, que era muyto proveitoso, pedindome que ouvesse por bem e mandasse que, por tempo de tres annos, nenhuma pessoa o podesse enpremir sem liçença delle doutor, por quanto era em seu prejuizo, e visto por mim seu pedir e avendo respeito ao que diz: ei por bem e por este mando que pello dito tempo de tres annos, que se começaráo da noteficaçam deste em diante, nenhuma pessoa, de qualquer calidade e condiçam que seja, possa enpremir nem mandar enpremir por nenhuma via o dito livro sem licença do dito doutor...19

Segundo assinalou o governante, a iniciativa da publicação da obra partiu de Garcia de Orta. Realçando a formação académica do médico, não se coibiu de aludir ao "Doutor" de forma respeitosa. Mais do que apenas a garantia da protecção dos direitos de autor relativos aos conteúdos, este Privilégio revelou, de forma inequívoca, a atitude cortês do poder político face ao trabalho do "físico d'El Rei".

Redigida pelo médico, a dedicatória, foi dirigida "Ao muyto illustre senhor Martim Afonso de Sousa do conselho Real senhor das villas de Alcuentre, e o Tagarro, seu criado o doutor Orta

18 Sobre o impacto que a obra de Garcia de Orta teve na Europa de então, nomeadamente através das versões latinas de CLusıus, Aromatum et simplicium (Antuérpia, 1567) assim como das suas traduções em italiano e francês e sobre as obras em castelhano elaboradas a partir da de Orta, como a de Juan FRAGOSO, Discurso de las cosas aromáticas (Madrid, 1572) e Cristóvão da CosTA, Tractado de las drogas (Burgos, 1578) há uma extensa bibliografia. Destacam-se os trabalhos: Teresa Nobre de CARvalHo, "A apropriação de Colóquios dos Simples por dois médicos ibéricos de Quinhentos", in Palmira Fontes da Costa e Adelino CARDoso (orgs.), Percursos na história do livro médico (1450-1800). Lisboa, Edições Colibri, 2011, pp. 59-72 e Florike EGMOND, The world of Carolus Clusius: Natural History in the making: 1550-1610. Londres, Pickering \& Chatto, 2010.

19 Garcia de OrTA, Colóquios dos Simples, op. cit., vol. 1, p. 3. 
lhe deseja perpetua felicidade com inmortal fama pera seus decendentes." ${ }^{20}$ Garcia de Orta intitulou-se "doutor" mas também "criado" do "ilustre" fidalgo que pertencia ao "Conselho Real". O recurso a uma linguagem clientelar, táo usual neste tipo de carta, onde imperava a cortesia e a deferência, mais do que afastar as duas personalidades, tornou-as solidárias. Este aparente cumprimento de um protocolo da expressão escrita parece revelador de um dos objectivos de Orta: reestabelecer a solidez da imagem do seu patrono e amigo. ${ }^{21}$ Orta serviu-se assim deste espaço para descrever, a todos quantos no Reino censuravam Martim Afonso de Sousa, quem este era aos olhos do público asiático. O herói que muitos recordavam, entre feitos grandiosos e decisóes controversas tinha, afinal, permitido que muito do saber reunido na obra viesse a lume. ${ }^{22}$

Com este gesto, Orta saldava uma dívida que ao zarpar de Lisboa, em 1534, contraíra com Martim Afonso de Sousa, o então Capitão-Mor da Armada. ${ }^{23}$

Ao longo da Carta, Garcia de Orta recorreu a numerosas referências clássicas, colocando Martim Afonso ao nível dos grandes heróis da Antiguidade. A familiaridade do fidalgo com os textos antigos foi realçada por Orta no Colóquio $2^{\circ}$, do aloés. Neste, Orta recordou a leitura da vida de S. Silvestre, narrada por Platina, que fizera em casa do seu amigo. ${ }^{24}$ A convivência entre os dois homens manifestava-se não apenas pelas relações de vassalagem que Orta insistiu em realçar, mas também pela partilha dos espaços, das leituras e dos saberes.

20 Garcia de ORTA, Colóquios dos Simples, op. cit., vol. 1, pp. 4-5. Martim Afonso de Sousa é uma figura fascinante da nossa História. Não pretendemos detalhar a sua biografia. Esta foi recentemente analisada por Alexandra PelúcIA, Martim Afonso de Sousa e a sua Linhagem: Trajectórias de uma elite no Império de D. João III e D. Sebastião. Lisboa, CHAM, 2009. No âmbito deste ensaio recorremos amiúde a esta pesquisa.

21 Ao longo desta carta, Garcia de Orta usou vários epítetos para apelidar Martim Afonso de Sousa: para além do referido "muito ilustre Senhor" socorreu-se de um "ilustríssimo Senhor" e da "vossa senhoria". Utilizando estas formulações, o médico subalternizou-se e enalteceu os feitos e valor daquele cuja "fortaleza é tão conhecida não tão somente por todas as três partes do mundo, mas pela outra quarta parte, que agora os cosmógrafos acrescentam". Garcia de ORTA, Colóquios dos Simples, op. cit., vol. I, p. 5.

22 Sobre as polémicas em torno da governação de Martim Afonso de Sousa à frente do Estado da Índia voltaremos mais adiante.

23 Face à alegada ascendência judaica de Garcia de Orta e ao crescente clima de instabilidade que se vivia em Lisboa devido à iminente instauração do Tribunal da Inquisição em Portugal (1536), deixar a capital do Reino afigurava-se a melhor solução. Embarcado como médico pessoal do Capitão-Mor da Armada a 12 de Março de 1534, Garcia de Orta viu a sua vida amparada pelo, então, inviolável estatuto de Martim Afonso de Sousa. A este respeito vide: Augusto da Silva Carvalho, "Garcia d'Orta", Revista da Universidade de Coimbra 12 (1934), pp. 80-82.

24 Segundo Ficalho, Orta referia-se a Platianae de vitis pontificum historia. Garcia de ORTA, Colóquios dos Simples, op. cit., vol. 1, p. 40. 
Na sua dedicatória, Orta incluiu Martim Afonso de Sousa no seu projecto editorial reconhecendo-o como grande impulsionador daquele trabalho: "e porque o vosso conselho he mandado pera mi, determinei de fazer este breve tratado". 25

O médico acrescentou:

"mas temia o oçioso povo e mordaces linguoas, por onde o tratado tinha neçesidade de hir arrimado a quem o defendese dellas, assi como fazem os esprementados agricultores que, querendo plantar algumas dellicadas plantas as arrimam a alguns fortes arvores pera que as defendam dos tempestuosos ventos e fortes chuivas e asperas geadas, assi quis eu plantar esta fraca planta debaixo do emparo de vossa senhoria, com o qual será defendida de toda a mór parte do mundo..."26

Martim Afonso de Sousa surgiu assim como aquele que assegurava a protecção da obra das censuras dos leitores. Não deixa de ser interessante realçar que este representante do poder político, famoso no Oriente como no Ocidente, foi apresentado no trabalho de Orta como protagonista na busca de uma verdade científica. Convém aqui sublinhar que, apesar deste género de discurso laudatório ser usual nos textos preliminares das obras então publicadas, nem sempre era tão explícita a participação do protector no âmago do projecto científico. Um dos aspectos curiosos que ressalta da leitura deste tratado é o aparente envolvimento de Martim Afonso de Sousa na construção do saber contido nos Colóquios. Ao longo da obra, Orta detalhou múltiplos episódios que o fidalgo protagonizou e parecem atestar esta co-responsabilidade do nobre na reconfiguração do saber divulgado por Orta. ${ }^{27}$ Esta participação efectiva do aristocrata num projecto erudito contribuiu para descrever Martim Afonso de Sousa como um fidalgo que, para além dos feitos heróicos, se destacava pelo seu empenho na busca de novos saberes. Cabe ainda recordar que a curiosidade científica e as qualidades de observação de Martim Afonso tinhamno levado a apresentar a Pedro Nunes (1502-1578) pertinentes questóes ligadas à navegação. ${ }^{28}$

Ao longo da sua obra, Garcia de Orta realçou os nomes de outros governantes e religiosos que lhe trouxeram importantes esclarecimentos ou empolgantes questóes relativas ao mundo

25 Garcia de ORTA, Colóquios dos Simples, op. cit., vol. 1, p. 4.

26 Garcia de OrTA, Colóquios dos Simples, op. cit., vol. 1, pp. 4-5.

27 O conhecimento relativo aos recursos naturais revestia-se de enorme importância estratégica para o governo do Estado da Índia. Para além disso, Martim Afonso estava pessoalmente empenhado no comércio de alguns produtos orientais, como foi o caso das avultadas quantidades de anil, lacre e gengibre que pretendia transaccionar ou expedir para o Reino. Também a colocação de vedores de fazenda da sua inteira confiança em postos chave, atesta bem o valor que dava ao comércio destes recursos analisados por Orta. Alexandra Pelúcia, Martim Afonso de Sousa e a sua Linhagem, op. cit., pp. 221-229.

28 Luís de Albuoueroue, Martim Afonso de Sousa. Mem Martins, ALFA, 1989, pp. 76-77 e Alexandra PelúciA, Martim Afonso de Sousa e a sua Linhagem, op. cit., p. 140. 
natural da Ásia. Uma nova elite esclarecida deixava um contributo indelével para esta inovadora descrição dos recursos naturais do Oriente.

Orta terminou a epístola, justificando a opção da redacção em português:

Bem pudera eu compor este tratado em latim, como o tinha muytos annos antes composto, e fora a vossa senhoria mais aprasível; pois o entendeis milhor que a materna linguoa, mas traladeo em portugues por ser mais geral, e porque sei que todos os que nestas indianas regiōes habitam, sabendo a quem vai entitulado, folgaram de o leer. ${ }^{29}$

Nesta alusão à familiaridade de Martim Afonso com o Latim, o médico parece querer recordar o nobre berço e a brilhante formação que o fidalgo gozou na corte do príncipe D. João. Com notável habilidade, Garcia de Orta justificou a sua decisão. Mais do que enaltecer as suas virtudes de académico, o médico pretendia que as gentes "que nestas indianas regióes habitam" recordassem, através da sua obra, os feitos e a memória de Martim Afonso de Sousa. Nesta Carta, cheia de subtilezas, para além de enaltecer as múltiplas qualidades de Martim Afonso de Sousa, o médico identificou uma parcela importante do público a quem a obra se destinava: os seus leitores residentes na Ásia.

\section{MARTIM AFONSO DE SOUSA: PROTECTOR OU PROTEGIDO?}

Martim Afonso de Sousa desempenhou funçôes militares e governativas no Oriente em dois períodos distintos: Capitão-Mor da Armada (1534-1538) e Governador (1542-1545). ${ }^{30}$ Como acima referimos, Garcia de Orta partiu para a Índia em 1534, a bordo da nau Rainha capitaneada por este fidalgo. Como as suas funçóes de médico pessoal do capitão obrigavam, acompanhou-o em todas as campanhas militares.

Alguns biógrafos de Garcia de Orta admitem que a relação entre os dois homens já vinha dos tempos de Lisboa. ${ }^{31}$ Apesar de não termos, até ao momento, reunido evidências seguras sobre este relacionamento, o certo é que, imediatamente após terminar os estudos médicos nas universidades castelhanas, Orta se instalou em Castelo de Vide. Só após um período

29 Garcia de OrTA, Colóquios dos Simples, op. cit., vol. 1, p. 5.

30 Sobre a actividade de Martim Afonso de Sousa no Brasil e no Oriente, vide: Alexandra PelúcıA, Martim Afonso de Sousa e a sua Linhagem, op. cit., pp. 127-255.

31 O Conde de Ficalho, suportando-se nos escritos de Barbosa MACHADO, faz recuar a amizade destes dois personagens aos tempos da mocidade. $O$ estudioso admite mesmo ter sido Lopo de Sousa, pai de Martim Afonso de Sousa, a custear os estudos médicos de Orta. Conde de Ficalho, Garcia de Orta e o seu tempo, op. cit., pp. 65-84. 
experimental, em que desenvolveu actividade clínica sob a vigilância de um médico desta cidade, e a aprovação num exame realizado perante o Físico-Mor, é que Orta viajou até Lisboa. ${ }^{32}$ O médico aproximou-se então dos Estudos Gerais de Lisboa, procurando, desde finais da década de 1520, integrar o mundo académico da capital. ${ }^{33}$

Quanto ao fidalgo, deixando Lisboa logo a seguir à morte de D. Manuel I para acompanhar de regresso a Castela a Rainha viúva, D. Leonor, por lá casou com D. Ana Pimentel. ${ }^{34}$ A união das famílias Sousa e Pimentel já tinha tradição e Martim Afonso tirou partido da sua permanência no Reino vizinho para reestabelecer laços entre as linhagens. ${ }^{35}$

O fidalgo permaneceu alguns anos próximo da corte castelhana. Segundo relatou, nas contendas franco-castelhanas combateu ao lado das tropas imperiais, o que lhe valeu um louvor público por parte de Carlos V (g.1519-1556). ${ }^{36}$ Como escreveu, o monarca chegou mesmo a

32 Para os licenciados em medicina pelas universidades estrangeiras, o Regimento do Físico-Mor de 1521 exigia um período de estágio acompanhado ao qual se seguia um exame perante o Físico-Mor do reino. Sobre este Regimento vide: Tello da FonseCA, História da farmácia Portuguesa através da Legislação. Porto, Empresa Industrial Gráfica do Porto, 1935, vol. 1, pp. 27-34. Após a conclusão dos estudos académicos, a residência de Orta em Castelo de Vide está atestada por dois documentos datados de Abril de 1526, presentes na Chancelaria de D. João III (Livros 12, fl. 43 v e 36, fl. 97). Nestes, o FísicoMor Diogo Lopes, após o exame ao candidato, considerou o licenciado Garcia de Orta, "morador em Castelo de Vide", "autossuficiente e idóneo assim na teórica como na prática" e autorizou-o a "andar de mula". Publicadas em finais do século xıx no Archivo da Pharmacia da Índia Portugueza por Pedro José da SILVA e analisadas pelos principais biógrafos do médico foram recentemente retomadas por Teresa Nobre de CARVALho na sua dissertação de Doutoramento, O mundo natural asiático aos Olhos do Ocidente, op. cit., pp. 68-80.

33 Sobre a passagem de Orta pelos Estudos Gerais de Lisboa, vide: Joaquim Teixeira de CARVALHo, Homens de outros tempos. Coimbra, Imprensa da Universidade, 1924 e Luís de PINA, "Garcia de Orta e o Magistério Universitário de Filosofia Natural em Lisboa", O Médico, vol. 636 (1963), pp. 3-26.

34 "e fiquei servindo até que El-Rei D. Manuel faleceu e a rainha D. Leonor foi para Castela, e fui com ela e lá casei com minha mulher", Luís de Albugueroue, Martim Afonso de Sousa, op. cit., p. 68. Este trecho encontra-se integrado na "Brevíssima e sumária relação que fez de sua vida e obras", datada de 1557 e atribuída a Martim Afonso de Sousa. A epístola é dirigida à "Sereníssima Senhora Rainha Dona Catarina, mulher de El-Rei D. João, o terceiro, estando ela na regência dos reinos. A qual relação se achou escrita de sua própria mão e letra muito tempo depois dele morto." Foi desta carta, publicada e comentada por Luís de Albuquerque, que retirámos elementos biográficos de Martim Afonso que nos permitiram ilustrar este ensaio. O rigor histórico de muitos dos episódios relatados faz com que esta "Brevíssima relação" seja tomada como uma autobiografia de Martim Afonso de Sousa. Tirando partido do então recente falecimento do Rei, o fidalgo não quis deixar de reivindicar perante a Regente as recompensas que este the prometera. Luís de Albuquerque não se coibiu de classificar esta atitude como "oportunismo que tomava o aspecto de pura chantagem". Luís de AlbuQueroue, Martim Afonso de Sousa, op. cit., pp. 67-84.

35 Sobre a promoção política e social de Martim Afonso através deste matrimónio e em relação à integração da família Pimentel entre os Grandes e Titulares de Espanha vide: Alexandra Pelúcia, Martim Afonso de Sousa e a sua Linhagem, op. cit., pp. 111-123.

36 "e assim de caminho nos fomos descer ao paço e beijar a mão do imperador [Carlos V]; e ele me disse palavras públicas muitas e de tantos gabos do que eu fizera, diante de toda a corte, de que eu podia ter muita vaidade...", Luís de Albuqueroue, Martim Afonso de Sousa, op. cit., pp. 68-69. Alexandra PeLÚciA, Martim Afonso de Sousa e a sua Linhagem, op. cit., p. 117. 
convidá-lo para entrar ao seu serviço. Apesar da generosidade da oferta, Martim Afonso sentiuse na obrigação de declinar. Deste modo, afirmou a sua rectidão de carácter em detrimento da ambição pessoal ou da sua projecção social.

A pedido de D. João III, regressou a Lisboa em 1525 acompanhando o séquito da prometida do rei, D. Catarina de Áustria. ${ }^{37}$ O nobre permaneceu na capital até 1529 , altura em que o monarca o enviou para o Brasil para proteger o território da ameaça dos avanços franceses. ${ }^{38}$ Para esta nomeação, além da confiança que o Rei nele depositava poderá ter contribuído a insistente

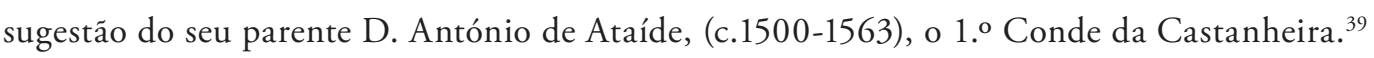

Martim Afonso de Sousa privou, desde muito cedo, com o príncipe D. João. Apesar de D. Manuel não o considerar uma companhia adequada para o infante, o gentil-homem, desde a juventude, frequentou o meio cortesão. Na referida "Brevíssima e sumária relação", que Martim Afonso dirigiu a D. Catarina, pode ler-se:

Neste tempo estavam alguma coisa diferentes El-Rei [D. Manuel I] e o príncipe [D. João], e, por parecer a El-Rei que eu o podia inclinar contra ele (o que nunca, Deus me perdoe, tal foi), me mandou dizer por D. Nuno Manuel e pelo Bispo do Funchal que me agradecia muito ir-me para casa de meu pai, e por lá estar um ano, e que ele me fazia toda a mercê que eu quisesse [...] e lhes respondi que eu vivia com o príncipe e era seu criado, e merecia dele muito mais honra e mercê da que eu merecia, e que não era homem para nenhum interesse me dobrar, para deixar de servir o senhor com quem vivia. ${ }^{40}$

Acompanhando de muito perto a educação do jovem herdeiro da Coroa, o fidalgo teve certamente uma instrução privilegiada. ${ }^{41}$ Uma formação humana integral e completa que, para além do ensino criterioso de disciplinas científicas e o treino intensivo da destreza física,

37 "E neste tempo se concertou o casamento de Vossa Alteza [D. Catarina] com El-Rei Nosso Senhor [D. João III], e ele me escreveu vir com Vossa Alteza e trazer minha mulher em sua companhia, o que fiz com muito gasto da minha fazenda e da alheia...", Luís de Albuqueroue, Martim Afonso de Sousa, op. cit., p. 69.

38 "e fiquei servindo assim na corte até à era de vinte e nove, que por El-Rei ter novas que no Brasil havia muitos franceses, me mandou lá em uma armada", Luís de Albuoueroue, Martim Afonso de Sousa, op. cit., p. 69.

39 Sobre a relevância da relação familiar entre D. António de Ataíde e Martim Afonso no seu percurso político e estratégico vide as cartas que este último lhe dirigiu a pedir intercessão junto do Rei em: Luís de Albuqueroue, Martim Afonso de Sousa, op. cit., pp. 12-20, 30-36 e 52-58, assim como Alexandra PelúCIA, Martim Afonso de Sousa e a sua Linhagem, op. cit., pp. 161-169. Recorde-se que D. António de Ataíde permaneceu na Corte até à morte de D. João III, em 1557.

40 Luis de Albuqueroue, Martim Afonso de Sousa, op. cit., p. 68.

41 Sobre a educação do príncipe D. João vide, entre outros: Ana Isabel BUESCU, D. João III, 1502-1557. Rio de Mouro, Temas e Debates, 2008, pp. 26-72. 
valorizava a doutrina cristã e o cultivo das virtudes. Com os mestres de D. João, Martim Afonso aprendeu a ser sábio e honrado. Com os exemplos de arrojados guerreiros, aspirou a deixar a sua marca na História. ${ }^{42}$ Não pretendemos aqui repetir caminhos trilhados por outros, mas apenas salientar a riqueza da bagagem científica, retórica, literária e o arrojo que revelou o Capitão-Mor da Armada de 1534.

Orta, por seu lado, nunca nos testemunhou a sua proximidade da corte de D. João. No entanto, o título de "Físico d'El Rey nosso senhor" que o frontispício do seu tratado proclama, atesta um reconhecimento, ao mais alto nível, do valor do seu trabalho. Em Colóquios dos Simples, Orta aludiu ainda à sua fazenda na ilha de Bombaim que lhe foi cedida pelo monarca, testemunhando a admiração e reconhecimento do soberano pelo seu trabalho. ${ }^{43}$

A leitura do tratado sugere-nos uma relação leal e cúmplice entre o fidalgo e o médico. Orta, que, referindo-se a Martim Afonso de Sousa, se intitulou "seu criado", afirmou ter escrito no tratado "cousas que me ensinastes, e outras, que eu aprendi na vossa escola militar e cortesãa." ${ }^{4}$

Esta escola "cortesã” referida por Orta, não parece limitar-se à passagem de Martim Afonso pelas cortes ibéricas. Para além da familiaridade com as cortes peninsulares o fidalgo dialogou com soberanos de outros meios cortesãos como Bahadur Shah, sultão indiano do Guzerate (1526-1537); Idalcão, sultão indiano de Bijapur (1535-1557); Bhuvaneka Bahu VII, rei cingalês de Kotte (1521-1551); Tabarija, o sultão de Ternate, (1532-1545); e o rajá de Cananor, Kolattiri (1527-1547). Orta não foi alheio aos contactos que o fidalgo estabeleceu com cada um destes governantes. Como veremos mais à frente, ao longo de Colóquios dos Simples, aludiu a encontros de Martim Afonso com algumas destas personalidades. ${ }^{45}$

42 Referimo-nos ao encontro, por volta de 1514, de Martim Afonso de Sousa com um dos seus heróis da arte da guerra: Gonzalo Fernández de Córdova, um valeroso guerreiro por quem o fidalgo nutria uma profunda admiração. Sobre o encontro deste combatente com o jovem, vide: Alexandra PeLúciA, Martim Afonso de Sousa e a sua Linhagem, op. cit., pp. 87-89.

43 José Gerson da Cunha, The origins of Bombay. Bombay, Society's Library, Town Hall, 1900, pp. 95-107.

44 Garcia de ORTA, Colóquios dos Simples, op. cit., vol. I, p. 5. É curioso notar que os termos usados por Martim Afonso de Sousa na carta que enviou à Regente para descrever a sua relação com D. João III são os mesmos que Garcia de Orta usou para descrever a sua relação com Martim Afonso.

45 Veja-se, por exemplo, Garcia de OrTA, Colóquios dos Simples, op. cit., vol. I, p. 119 e vol. 2, p. 101. 


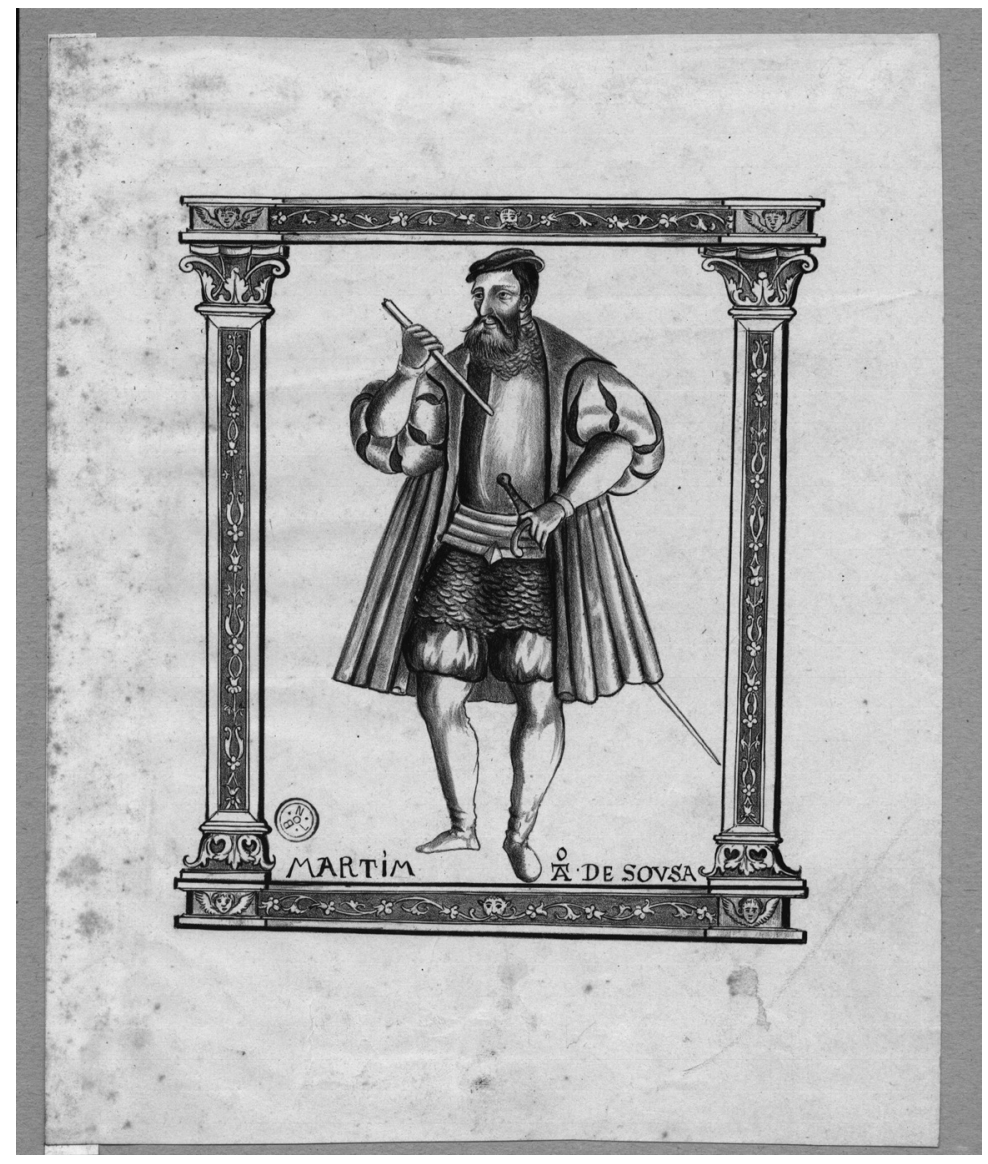

Figura 2 - Martim Afonso de Sousa exerceu funções militares e governativas na Índia em diferentes momentos: Capitão-Mor da Armada (1534-1538) e Governador (1542-1545). Foi com este fidalgo que Garcia de Orta partiu, em 1534, para Oriente e foi como seu médico privado que visitou as cortes de soberanos locais onde teve a oportunidade de confrontar o seu saber com o de outros práticos. (Cortesia da Biblioteca Nacional de Portugal)

Se a sugestáo de produzir a obra parece, como vimos, ter partido de Martim Afonso vale a pena esclarecer que papel desempenhou este fidalgo durante a sua governação no comércio de drogas e especiarias ou na melhoria da qualidade dos cuidados de saúde dos portugueses residentes em Goa.

Segundo o fidalgo narrou a D. Catarina, mal aportou em Goa, ao constatar a pobreza que grassava entre os portugueses, foi obrigado a tomar medidas drásticas para melhorar a qualidade de vida dos muitos soldados que deambulavam pelas ruas da cidade. Denunciando a 
inabilidade para governar dos seus antecessores, tomou a seu cargo todos quantos estes tinham votado ao abandono. ${ }^{46}$

Comparando a Índia que então encontrava com a que tinha conhecido anos antes, escreveu: “... achei a terra tão perdida que verdadeiramente não a conheci...”.

Segundo relatou, de imediato lançou máos à obra procurando repor a ordem pública e reorganizar as finanças reais. $\mathrm{Na}$ "Brevíssima e sumária relação...” escreveu:

Tudo isto foi logo remediado, porque para a necessidade dos soldados ordenei logo fidalgos que lhe dessem mesas, e comecei a entender na fazenda de Sua Alteza e [a] apertar com os feitores, de maneira que houve dinheiro, com que comecei a fazer pagamentos a esta gente pobre, e mandei lançar pregão que todo o homem que mais andasse pedindo esmola fosse açoutado publicamente. ${ }^{47}$

A entrega, em 1542, à Misericórdia da gestão do Hospital Real de Goa, delegando em homens da sua confiança o trabalho de organização, gestão, tratamento e administração de cuidados aos doentes e aos mais necessitados foi um enorme serviço prestado aos portugueses residentes na região. ${ }^{48}$

Como escreveu a D. Catarina:

Nos hospitais gastava El-Rei nosso Senhor muito dinheiro, de que os doentes haviam mui pequena parte e os seus oficiais quase toda; e para tirar este inconveniente, ajuntei-os com a Misericórdia, que foi um grande serviço de Nosso Senhor e de Sua Alteza, por quanto melhor curados foram os doentes daí por diante; e para que isto não arrefecesse ia todas as sextas-feiras ouvir missa ao hospital, onde estava e tomava larga informação de como a casa era servida. ${ }^{49}$

Ainda no decorrer deste mesmo ano, o Governador ordenou ao seu vedor de fazenda, Fernão Rodrigues de Castelo Branco, o estabelecimento de uma "Pauta de Mezinhas", onde o

46 Apesar de ser frequente a crítica do novo governante designado face ao trabalho desenvolvido pelos seus antecessores, Martim Afonso de Sousa, nas numerosas cartas que enviou ao Reino, nunca escondeu a especial antipatia que nutria por D. Nuno da Cunha (g.1529-1538). Luis de AlbuQueroue, Martim Afonso de Sousa, op. cit., pp. 9-58.

47 Luís de Albuqueroue, Martim Afonso de Sousa, op. cit., p. 76.

48 Estas decisões competiam aos Governadores e Vice-Reis. Anos antes, verificando o abandono a que eram votados muitos doentes e feridos, o Vice-Rei D. Francisco de Almeida (g.1505-1509) havia ordenado a construção do Hospital Real de Santa Cruz de Cochim para o qual destacou um físico, um cirurgião, enfermeiros e servidores. Catarina Madeira SANTOS, "Goa é a chave de toda a Índia". Perfil político da capital do Estado da Índia (1505-1570). Lisboa, CNCDP, 1999, pp. 153-197.

49 Luís de Albugueroue, Martim Afonso de Sousa, op. cit., p. 77. 
preço da generalidade das drogas, simples ou preparadas, fosse fixado e respeitado no Reino e na generalidade do Estado da Índia. Reformulando o velho "Regimento de Preços das drogas e mezinhas" de 1497, a "Pauta das Mezinhas" de 1542 permaneceu em vigor até $1573 .{ }^{50}$

Para além destas medidas de relevância social e estratégica, a gestão enérgica da terrível epidemia que assolou a cidade em 1543 deixou na memória de muitos sobreviventes a notável capacidade do fidalgo em enfrentar um dos males mais temíveis que grassava no Oriente: a cólera. ${ }^{51}$

Como descreveu Gaspar Correia, o flagelo dizimou, indiscriminadamente, crianças e velhos, homens e mulheres, ricos e pobres. Poucos dos afectados sobreviveram, e a cidade viveu momentos de angústia intensa. Para tentar serenar os ânimos, Martim Afonso proibiu os sinos das igrejas de tocar a dobrar e ordenou a autópsia a cadáveres. ${ }^{52}$

Esta investigaçáo directa das causas da doença, recorrendo a uma prática tão invulgar na época, é reveladora do interesse do Governador em compreender, para melhor dominar, o temível inimigo que tinha por diante. ${ }^{53}$ Garcia de Orta participou certamente nestas investigaçôes. Em Colóquios dos Simples, o médico integrou no "Colóquio décimo sétimo, do Costo e da Colérica passio", a primeira descrição sobre a etiologia desta enfermidade que, uma vez contraída, matava em 24 horas. ${ }^{54}$ Revelando-se conhecedor dos sinais e sintomas e detentor dos segredos da cura, o médico demonstrou, com o seu tratado, o imprescindível valor da sua presença em Goa. Uma valia que revelou através dos interlocutores de posses que fez entrar em cena neste "Colóquio do costo". O pajem de um suposto "D. Jerónimo", que irrompeu noite dentro por entre a sossegada conversa de Ruano e Orta, atesta bem a gravidade desta doença, cujo tratamento "não padece tardança". A prontidão com que o médico visitou o doente, inquiriu as gentes da casa, estabeleceu o diagnóstico e preconizou o tratamento, assim como

50 Esta lista de especiarias, mezinhas e formulações terapêuticas e respectivos preços de aquisição e venda, vigorou em todos os hospitais e boticas do Oriente durante mais de 30 anos. Durante a governação de D. Constantino de Bragança (g.1558-1561), os preços de alguns simples foram revistos e actualizados pelo então físico-mor Dimas Bosque, permanecendo o resto da lista inalterada até 1573 altura em que Duarte Lopes assinou uma nova Pauta de Mezinhas que entrou em vigor de imediato. Tello da FonseCA, História da Farmácia portuguesa através da legislação, op. cit., vol. 3, pp. 5-21 e Teresa Nobre CARVALHo, O mundo natural asiático aos olhos do Ocidente, op. cit., pp. 221-224.

51 Sobre este episódio, vide: Ines Županov, "Drugs, health, bodies and souls in the Tropics. Medical Experiments in Sixteenth century Portuguese India", The Indian Economic and Social History Review 39, 1 (2002), pp. 1-43.

52 Gaspar Correia, Lendas da India, (Rodrigo de Lima Felner ed.). Lisboa, 1864, vol. 4, pp. 288-289. O trecho foi integralmente reproduzido pelo Conde de Ficalho nas notas ao Colóquio $17 .{ }^{\circ}$ em Colóquios dos Simples, op. cit., vol. I, pp. 273-274.

53 Nesse mesmo ano, verificou-se uma onda de contestação por toda a Europa causada pela publicação da obra de André Vesálıo, De humani corporis fabrica libri septem. Basileia, ex of. J. Oporini, 1543, na qual o corpo humano era investigado a partir do seu interior, com grande minúcia de detalhes. Alguns anos mais tarde, D. João III viria a ordenar a entrega de cadáveres à Universidade de Coimbra com o intuito de nesta serem aprofundados os estudos de Anatomia.

54 Garcia de ORTA, Colóquios dos Simples, op. cit., vol. I, pp. 255-267. 
o diálogo franco que estabeleceu com o boticário pessoal do fidalgo parece justificar o respeito das elites portuguesas por Orta e sublinhar a pertinência do seu saber. ${ }^{55}$

Mas se a atitude do governante perante a ameaça desta epidemia mereceu a admiração dos funcionários régios destacados no Oriente, nem todas as decisóes de Martim Afonso foram aceites pelas elites portuguesas. Algumas atitudes do governador provocaram acesa controvérsia em Lisboa. Não deixam, por isso, de nos soar algo desafiantes as palavras que Orta inscreveu na carta dedicatória: "porque sei que todos os que nestas indianas regiôes habitam, sabendo a quem vai entitulado, folgarão de o leer."

$\mathrm{Na}$ verdade, ao longo da sua governação, Martim Afonso de Sousa tomou atitudes extremamente polémicas, condenadas no Reino pela generalidade da elite política. Se a sua ousadia em mandar construir um navio para fins comerciais ou a sua implicação na compra de pedras preciosas, lhe valeram a crítica do Rei e de D. António de Ataíde, outras atitudes mais gravosas indignaram as elites dirigentes do Reino. ${ }^{56}$

Como escreveu Alexandra Pelúcia,

Resultaria longa e fastidiosa a pormenorização dos temas sujeitos a denúncia. Em termos gerais, retenham-se as liberdades comerciais distribuídas, as expediçóes organizadas pelo governador, os problemas de Meale e do tesouro de Asad Kahan, os distúrbios ocorridos em Cananor após o assassinato do Cádi local, o deficiente abastecimento dos armazéns, o estado deplorável a que chegara a armada [...] e o escândalo mais recente de cunhagem de moeda de circulação corrente em Goa, os bazarucos, com menor percentagem de cobre. ${ }^{57}$

Não pretendemos detalhar cada um destes assuntos. Parece-nos, no entanto, evidente que, no Reino, a imagem do fidalgo tinha sofrido uma importante deterioração durante a sua governação no Oriente. A chegada apartada do seu navio a Lisboa, deixando para trás as outras naus da armada, atesta bem o desconforto que envolvia o seu nome.

$\mathrm{Na}$ "Brevíssima e sumária relação", à qual temos vindo a fazer referência, Martim Afonso revelou uma enorme audácia. O discurso do fidalgo parece sugerir a desconsideração a que tinha sido votado por muitos cortesãos. Importunando a Rainha viúva com solicitaçóes e pedidos, o nobre procurou, da forma que lhe pareceu adequada, reestabelecer a sua posição e cabedais. ${ }^{58}$ Fazendo-se valer da sua família numerosa, do bom nome de sua mulher, do já

55 Como demonstraremos mais abaixo, também as elites locais consideravam valioso o saber de Orta.

56 Estas repreensões foram-lhe comunicadas em carta que D. António de Ataíde the enviou em 1544. Alexandra PelúciA, Martim Afonso de Sousa e a sua Linhagem, op. cit., pp. 226-228.

57 Alexandra Pelúcia, Martim Afonso de Sousa e a sua Linhagem, op. cit., p. 240.

58 Talvez valha a pena não esquecer que o seu parente, D. António de Ataíde, o sólido interlocutor que 
antigo conhecimento que tinha da governante, que remontava à viagem de Tordesilhas para Lisboa, e tirando partido da fragilidade que a morte de D. João III deixara em aberto, o fidalgo encontrou em D. Catarina o apoio e amparo de que necessitava.

$\mathrm{Na}$ realidade, durante a sua regência (g.1557-1562), a Rainha veio a solicitar ajuda de Martim Afonso de Sousa. Não parece, no entanto, que este seu apoio ao fidalgo reunisse consensos. Como se pode ler num episódio relatado nos Ditos portugueses dignos de memória, o fidalgo dirigiu, em nome da Regente, as reunióes preparatórias que tiveram lugar em Lisboa, em 1562.59 No decorrer de uma dessas reunióes, ocorreu o episódio que o anónimo autor dos Ditos registou:

Sendo el-rei D. Sebastião de pouca idade e a Rainha D. Catarina, sua avó, que por ele governava, querendo largar o governo, mandou chamar as cortes; e, depois de chegados os procuradores de todos os povos do Reino, estando já juntos no lugar deputado para o auto, estando Martim Afonso de Sousa, que fora governador da Índia, sentado em uma cadeira para, em nome da rainha, lhes propor e praticar o para que foram chamados, por ela o ter escolhido para isso, começou a prática por estas palavras:

— Vós outros, Senhores, sois aqui vindos para Sua Alteza vos manifestar...

E, indo prosseguindo a sua prática, um Diogo Soares Homem, que era procurador de Lamego, sabendo que todos os procuradores que ali vinham eram cavaleiros muito honrados e os principais dos lugares que os elegeram, não lhe parecendo decentes as palavras do intróito com que Martim Afonso começara, atalhou-lhe passar avante com lhe dizer estas:

— Vós outros não estão aqui, nem Martim Afonso está na Índia. ${ }^{60}$

Martim Afonso tinha junto do Rei, abandonou a corte em 1557, pelo que o fidalgo já não podia contar com a sua intercessão.

59 Ditos portugueses dignos de memória é uma compilação de ditos, provérbios, anedotas, episódios e sentenças que circulavam no Reino, no século XVI. Permanecendo inéditos até ao século passado, conhecem-se diversas versões manuscritas, o que parece indicar a sua importante circulação. Reunidos por um autor anónimo, ilustram momentos do quotidiano português, ocorridos entre os reinados de Afonso V e D. Sebastião. Segundo José Hermano Saraiva, o compilador terminou a recolha perto de 1575. Elementos da nossa cultura oral, pela sua irreverência que não deixa ninguém de fora, estes ditos constituem preciosas achegas à narrativa historiográfica. Ditos portugueses dignos de memória. História íntima do século XVI anotada e comentada por José Hermano SaraIVA. Póvoa do Varzim, Publicações Europa-América, pp. 5-10. Para uma análise mais detalhada sobre as diversas versões manuscritas desta obra quinhentista vide Mário Justino SILVA, O rei e os nobres: imagens do quotidiano nos ditos portugueses dignos de memória (século xvı). Cascais, Patrimonia, 2004.

Ditos Portugueses dignos de memória, op. cit., p. 422. 
Como recordou Mário Justino da Silva, em muitos episódios relatados nos Ditos, o descurar o uso de uma fórmula adequada de tratamento pronominal dava azo, a frequentes queixas, ofensas e conflitos. ${ }^{61}$ Este reparo que o procurador de Lamego dirigiu ao fidalgo faz adivinhar alguma advertência a Martim Afonso. Apesar de a situação ocorrer num contexto em que era clara a confiança que D. Catarina depositava no fidalgo, o representante parecia querer recordar ao nobre que este apoio da Regente se aproximava do fim, já que, em breve, as Cortes reuniriam assinalando o encerramento do período de Regência de D. Catarina e portanto, a transição do seu poder. Com o cessar do apoio da Regente, vozes como as de Garcia de Orta contribuíam para manter viva a memória da grandiosidade dos feitos de Martim Afonso. ${ }^{62}$

De facto, encontrando numerosos entraves no Reino, a restauração do nome do fidalgo parece ter sido lenta. Afigura-se-nos, como tal muito oportuno, o aparecimento, em 1563, de uma obra inteiramente dedicada aos recursos naturais da Ásia, na qual a dedicatória enalteceu os feitos, saberes, arrojo e distinção de um fidalgo que, no Oriente, era saudado pela sua alta estirpe. ${ }^{63}$

Com as suas breves palavras, Garcia de Orta parece ter querido recuperar a memória do nobre e salientar a admiração que os portugueses espalhados por toda a Ásia nutriam pela sua pessoa e pelo trabalho que, durante a sua permanência no Oriente, realizara.

Não deixa de ser curioso que, ao associar Colóquios dos Simples a Martim Afonso, Garcia de Orta comprovava muitos dos feitos grandiosos que o fidalgo descrevera na "Brevíssima e sumária relação...”, de 1557, para além de o implicar nos complicados processos de conquista de mercados de especiarias e aromas e de aquisição de saberes relativos às maravilhas do Oriente.

Mas talvez o problema fosse um pouco mais profundo do que aparenta. Com o fim da regência de D. Catarina e o avizinhar de tempos de indefinição de governo, é possível que o investimento régio em pesquisas como a que Garcia de Orta apresentava fosse questionado. Martim Afonso surgia assim como um dos derradeiros elos ainda visíveis de um projecto construído ao longo de várias décadas e que, agora, com o apartamento da Regente, ameaçava desvanecer-se.

Convém sublinhar que, desde a sua chegada a Portugal, D. Catarina tinha revelado um enorme gosto pelas maravilhas do Oriente. Para além dos animais exóticos que mantinha nos seus zoológicos privados, a Rainha coleccionava objectos raros, artigos de luxo e preciosidades asiáticas. ${ }^{64}$ Em Goa, Cochim e Malaca mantinha homens da sua confiança que encarregava

61 Mário Justino da SILVA, 0 rei e os nobres, op. cit., pp. 71-78.

62 Foi também no final de 1562 que Garcia de Orta terminou Colóquios dos Simples no qual redigiu a carta dedicatória a Martim Afonso de Sousa.

63 É com alguma ironia que verificamos que no momento em que a obra fica finalmente pronta, a Regente já tinha renunciado ao cargo, deixando no seu lugar o cardeal Infante D. Henrique (r.1562-1568), Inquisidor-Mor do Reino.

64 O fascínio de Catarina de Áustria pelas maravilhas e raridades tem sido alvo de aturado estudo por Annemarie Jordan. Para além de peças de grande requinte adquiridas pelos seus feitores europeus em Roma, Génova, Florença, Milão, Valência, Sevilha, Medina del Campo e Paris, esta investigadora, 
de adquirir pedras preciosas e raridades como cocos-das-Maldivas e bezoares, para além de porcelanas e outras maravilhas exóticas que guardava nos seus aposentos ou distribuía pelos seus familiares. ${ }^{65}$

\section{MARTIM AFONSO DE SOUSA E A NOVIDADE}

O respeito por Martim Afonso de Sousa era, aliás, compartilhado por alguns dos soberanos locais. Ao longo de Colóquios dos Simples, em diversas ocasiōes, Orta relatou a sua experiência enquanto médico pessoal do então Capitão-Mor da Armada, durante a sua passagem pelas cortes destes governantes. Nestes episódios, ocorridos entre 1534 e 1538, Garcia de Orta testemunhou a sua passagem pelas cortes de "Nizamoxa" ${ }^{66}$ e de Bahadur. ${ }^{67}$ Foi em algumas destas ocasióes que Orta fez valer o seu saber médico perante os dirigentes locais e os sábios que os rodeavam.

Foi enquanto físico do Capitão-Mor que Orta visitou a corte do rei do Balagate "cujo pay curey muitas vezes, e ao filho algumas" ${ }^{68}$, onde esclareceu a diferença entre folio e betre ${ }^{69}$ e provou as mangas mais saborosas. ${ }^{70}$

assinalou na colecção real artigos orientais provenientes de Goa, Ceilão Macau, Malaca, Japão, China e Ryukyu. Annemarie Jordan, A rainha colecionadora. Catarina de Áustria. Maia, Círculo de Leitores, 2012, p. 110. De entre os numerosos estudos que esta estudiosa tem publicado sobre o assunto, destacamos: Annemarie Jordan GsCHWEND, "Catarina de Áustria: Colecção e Kunstkammer de uma princesa renascentista", Oceanos 16 (1992), pp. 62-70; Annemarie Jordan GsCHWEnd, "Marvels of the East. Renaissance curiosity collections in Portugal» in Nuno Vassallo e SILvA (coord.), A herança de Rauluchantim. Lisboa, 1996, pp. 82-127 e Annemarie Jordan, A rainha colecionadora. Catarina de Áustria, op. cit., pp. 99-126.

65 De entre a vasta lista de funcionários encarregados de adquirir raridades para a rainha destacamse nomes como os do ourives da corte Diogo Vaz, do feitor Manuel Botelho ou do moço-de-câmara António Correa. Annemarie JoRdAn, A rainha colecionadora. Catarina de Áustria, op. cit., pp. 110-111.

66 "Nizamoxa" resulta de uma adaptação para português de "Nizam Shâh", termo que designava o Sultão de Ahmadnagar. No período em que Garcia de Orta permaneceu no Oriente reinaram Burhan Nizam Shâh (r.1503-1553) e Husain Nizam Shâh (r.1554-1565). Ao longo de Colóquios dos Simples, Garcia de Orta refere-se a estes governantes com admiração e apreço.

67 Bahadur Xá foi Sultão de Guzarate, (r.1526-1537). Perante a ameaça Mogol, o Xá viu-se obrigado a socorrer-se da ajuda dos portugueses para proteger as suas possessões. Segundo consta, Martim Afonso de Sousa conquistou a confiança do soberano e manteve relações frutuosas com este tendo firmado, em 1535, o Tratado de Baçaim, através do qual Damão, Diu, Bombaim e Baçaim passaram para a posse dos portugueses. O Sultão morreu em circunstâncias ainda não esclarecidas.

68 Garcia de ORTA, Colóquios dos Simples, op. cit., vol. 1, p. 119.

69 Garcia de OrTA, Colóquios dos Simples, op. cit., vol. 2, pp. 393-394.

70 Garcia de OrTA, Colóquios dos Simples, op. cit., vol. 2, p. 101. 
Foi ao serviço de Martim Afonso que o físico conheceu a corte do Sultão do Guzarate, “o maior rey que avia na Mourama." ${ }^{71}$ Nesta, Orta testemunhou o hábito de mastigar o bangue ${ }^{72}$ e pôde observar as práticas médicas de outros.

Ao longo da sua vivência asiática, Orta observou e ajuizou os costumes dos médicos locais. Presenciar como outros estabeleciam os diagnósticos, avaliar as práticas terapêuticas que preconizavam, levou-o a questionar a sua própria modalidade de curar. Em algumas circunstâncias, teve mesmo de admitir que as práticas clínicas de físicos árabes e hindus eram mais eficazes do que as europeias. Corrigindo algumas metodologias ocidentais, vulgarizando as práticas de outros nas equipas médicas hospitalares, permitindo o acesso quotidiano dos físicos gentios a sua casa, inquirindo os seus colegas sobre os seus conhecimentos, Orta edificou um saber híbrido onde convergiam as práticas de tradiçôes médicas distintas e que se revelava, globalmente, mais eficaz no combate aos males que grassavam no Oriente. ${ }^{73}$

Foi durante as suas deslocaçóes às cortes de Cambaia ou do Balagate que Orta estabeleceu os principais contactos com hakims. ${ }^{74}$ Estes homens letrados poucas vezes se deslocaram a Goa, já que não ponderavam a possibilidade de ocupar lugares de subordinação nos hospitais lusitanos e, aparentemente, os portugueses não estavam dispostos a considerá-los como iguais. Foi assim, no âmbito de um meio político definido, que Orta confrontou o seu saber com o dos seus colegas árabes: homens com quem discutiu conteúdos de textos e debateu as práticas médicas usadas, mas também de quem aprendeu múltiplos saberes sobre a sinonímia e as propriedades terapêuticas das drogas locais.

Por terem um ensino médico baseado, em grande parte, nos mesmos textos, por praticarem nas cortes de soberanos locais e por estarem mais perto das drogas orientais do que os sábios europeus, Orta dedicou ao saber destes médicos particular atenção. Por vezes, salientava a proximidade das práticas dos médicos árabes e europeus, e o seu distanciamento face às terapêuticas dos físicos gentios. ${ }^{75}$ Mas Orta confiava no sistema médico em que se formara. Como salientou

71 Garcia de OrTA, Colóquios dos Simples, op. cit., vol. 2, p. 140.

72 Garcia de ORTA, Colóquios dos Simples, op. cit., vol. 1, p. 97.

73 Parece-nos oportuno realçar alguns estudos sobre esta temática, como os de Ricardo JorGe, La médecine et les médecins dans l'éxpansion mondiale des Portugais. Lisboa, Tip. Seara Nova, 1935; Harry FriedenWALD, "The medical pioneers in the East", op. cit., pp. 487-501 ou Luís de PinA, As ciências na história do Império Colonial Português (séculos xV a xIX), op. cit.; ver também Kapil RAJ, Relocating Modern Science. Circulation and the construction of knowledge in South Asia and Europe, 1650.1900. Nova Iorque, Palgrave Macmillan, 2007, pp. 1-26; Teresa Nobre de CARVALHo, O mundo natural da Ásia aos olhos do Ocidente, op. cit., pp. 257-270.

74 Garcia de ORTA, Colóquios dos Simples, op. cit., vol. 2, p. 147; P. GaITONDE, Portuguese pioneers in India. Spotlight in medicine. Bombay, Popular Prakashan, 1983, p. 139.

75 Michael PeArSON, "Hindu medical practices in Sixteenth-Century Western India: Evidence from Portuguese sources", Portuguese Studies 17 (2001), pp. 100-113. 
a Ruano, "primeiro provo as mezinhas dos meus doutores, quando me não aproveitam, tomo as dos Brâmanes desta terra." ${ }^{76}$

A sua dependência face aos médicos gentios era de outra ordem. Estes homens guardavam um tesouro: o saber relativo às propriedades terapêuticas das plantas locais. Assim, a desqualificação destes detentores de um património insondável era apenas aparente. Na verdade, Orta estava ciente que o saber dos vaydias era um poderoso aliado que os portugueses no Oriente tinham que conquistar. ${ }^{77}$

Não nos restam hoje dúvidas de que, nos hospitais portugueses do Oriente, se aviavam receitas de mezinhas locais. As listas de botica que hoje conhecemos testemunham o uso vulgar de drogas indígenas. ${ }^{78}$

\section{D. CONSTANTINO DE BRAGANÇA E O SEU MÉDICO}

Atestando a sua adesão aos produtos usados na farmacopeia local, Dimas Bosque (s/d) contribuiu para consolidar as novidades apresentadas no tratado de Orta. O testemunho deste médico valenciano revelou-se imprescindível. A ele se deveram dois dos paratextos ${ }^{79} \mathrm{e}$ a descrição de novidades, no Colóquio 58. ${ }^{\circ}$, "Das cousas novas". ${ }^{80}$

Como relativamente a tantas outras personalidades do seu tempo, pouco se sabe sobre a vida de Dimas Bosque. Como escreveu Jaime Walter: "Dimas Bosque [...] formou-se em Medicina. Se completou o curso em Coimbra, não se pode afirmar, pois a única conclusão que podemos extrair das suas palavras é ter assistido às liçóes e ter contactado com o Professor da Universidade Dr. Tomás Rodrigues da Veiga." ${ }^{81}$

76 Garcia de ORTA, Colóquios dos Simples, op. cit., vol. 2, p. 138.

77 Sobre a importância das plantas asiáticas para os portugueses vide K. S. MATHEW, "The Portuguese and the study of medicinal plants in India in the sixteenth century", op. cit., pp. 369-376; Sobre a relevância dos saberes locais no contexto dos impérios ibéricos vide: Daniela BLEICHMAR, Science in the Spanish and Portuguese empires, 1500-1800, op. cit., pp. 219-232; Jorge CAÑIZARES-EsGUerRa, "Iberian Science in Renaissance: ignored how much longer?", op. cit., pp. 86-124; Londa SCHIEBINGER and Claudia SWAN, Colonial Botany, op. cit., pp. 83-99 e 119-133 e Palmira Fontes da CostA, Teresa Nobre de CARVALho, "Between East and West: Garcia de Orta's Colloquies and the circulation of medical knowledge in the sixteenth century", Asclepio, Revista de Historia de la Medicina y de la Ciencia 65, 1 (enero-junio 2013), pp.1-13.

78 Banha de AndRADE, "Drogas do Oriente", Arquivo do Centro Cultural Português 3 (1971), pp. 112-188 e Jaime Walter, "Simão Álvares e o seu rol das drogas da Índia", Studia 10 (1962), pp. 117-149.

79 Referimo-nos a duas cartas: uma dirigida ao leitor e outra a Tomás Rodrigues da Veiga. Garcia de ORTA, Colóquios dos Simples, op. cit., vol. 1, pp. 10-13.

80 Garcia de OrTA, Colóquios dos Simples, op. cit., vol. 2, pp. 371-384.

81 Jaime Walter, "Dimas Bosque e as sereias", Studia 12 (1963), p. 262. 
Dimas Bosque chegou à Índia, em 1558, como físico-mor de D. Constantino de Bragança (g.1558-1561). Filho de D. Jaime de Bragança e de D. Leonor de Mendoza, D. Constantino era um homem de nobre linhagem e da inteira confiança de D. João III, como o atestam as importantes missóes diplomáticas que desenvolveu, em França, junto da corte de Henrique II. Durante o seu governo do Estado da Índia, D. Constantino revelou a integridade do seu carácter mas também uma rigorosa ortodoxia. Motivado pelo ideal da Contra-Reforma, a sua governação deu mostras de grande intolerância religiosa. ${ }^{82}$ Homem crente, de convicçôes fortes, a ele se deveram importantes campanhas militares. ${ }^{83}$

Como as suas funçóes o exigiam, o licenciado Bosque acompanhou o Vice-Rei nas expediçôes guerreiras. Conforme relatou, na campanha do Jafanapatão, face ao esgotamento das drogas de botica que trazia, viu-se forçado a buscar na região novas soluçóes terapêuticas. Ao inquirir as populaçóes locais, o médico deu-se conta da enorme diversidade de ervas e plantas com propriedades curativas que eram usadas na farmacopeia tradicional. Convencido, pela sua experiência, da eficácia destas novas mezinhas, Dimas Bosque alargou o leque de drogas à disposição dos médicos e boticários portugueses. Através de Colóquios dos Simples, Dimas trouxe ao conhecimento dos leitores novas drogas como os marmelos-de-Benguela ou a pedra-de-Malaca. ${ }^{84}$

Como atrás referimos, Dimas Bosque reviu e actualizou os preços da Pauta das Mezinhas que se usavam no Hospital Real de Goa. O médico desempenhou as funçóes de Físico-mor, provavelmente até ao regresso de D. Constantino ao Reino em 1561. A partir de então estabeleceu-se na Índia tendo arrematado a ilha de Santa Cruz, em Setembro do mesmo ano. ${ }^{85}$

Desconhecemos se D. Constantino esteve directamente implicado na publicação de Colóquios dos Simples. Regressado ao Reino numa altura em que a obra ainda permanecia manuscrita, manteve a sua presença no texto através do testemunho do seu físico pessoal.

Supóe-se que o licenciado Dimas Bosque animou a actividade científica do Colégio de São Paulo de Goa. Os eventos que organizou nesta instituição Jesuíta teriam a maior relevância para a afirmação de Goa como pólo cultural no Oriente. ${ }^{86}$ Também a carta que endereçou de Goa, em 1565, ao Reitor do Colégio de Córdova, o Padre João Baptista de Ribera SJ, descrevendo o

82 Em Oriente Conquistado encontra-se uma carta que o P. Luís Fróis dirigiu a um seu irmão do Colégio romano, na qual revelou as mudanças introduzidas por D. Constantino na Igreja, em Goa. Aquilino RIBEIRO, Constantino de Bragança VII Vizo-Rei da Índia. Venda Nova, Bertrand Editora, 1987, pp. 182-185.

83 Sobre este Vice-Rei, vide, entre outros, Aquilino RıBEıro, Constantino de Bragança..., op. cit., ou Charles R. Boxer, O Império Colonial Português 1415-1825. Lisboa, Edições 70, 2001, pp. 77-93.

84 Garcia de ORTA, Colóquios dos Simples, op. cit., vol. 2, pp. 371-384.

85 Augusto da Silva Carvalho, "Garcia d'Orta", op. cit., p. 238.

86 Num destes momentos, ocorrido em 1559, no Colégio de São Paulo, Garcia de Orta pertenceu ao grupo de jurados que avaliou as provas de um jovem noviço. O episódio relatado pelo irmão Luís Fróis foi publicado na Documentação das Missões do Padroado Português do Oriente, vol. VII, pp. 297-236. 
"estupendo milagre da natureza" que examinara alguns anos antes na ilha do Manar, atesta a sua permanência no Oriente depois da saída do Governador. Para além da descrição daqueles peixes "obra admirável do Criador", a carta revelou-se da maior importância, já que comprova que Dimas Bosque manteve relações epistolares com os mais altos representantes dos Colégios da Companhia de Jesus estabelecidos na Península Ibérica e, muito provavelmente, exercia prática clínica no Colégio dos Jesuítas de Goa e no respectivo Hospital. ${ }^{87}$

Não é, por isso, surpreendente o respeito com que Orta se referiu a este médico. A admiração de Orta surgiu plasmada em algumas das suas alusôes ao físico de Valência: "hum físico letrado e homem que fala verdade em seus ditos" 88 ou "o licenciado Dimas Bosque, pessoa de muito boas letras, e homem de muyta verdade nas curas que faz [...] e ao menos seivos dizer que me avia de dizer verdade." ${ }^{89}$ A mútua afeição entre os médicos ficou claramente demonstrada no Colóquio 58. ${ }^{\circ}$, no qual Garcia de Orta convidou Dimas Bosque a emendar os erros que tivesse encontrado em Colóquios dos Simples. Ao sujeitar-se à correcção de um colega claramente menos conhecedor das práticas e saberes locais do que ele próprio, Orta submeteu-se ao que Dimas representava: uma harmoniosa convivência com o poder de um Bragança.

A epístola que Dimas Bosque dirigiu ao leitor, na qual traçou alguns passos da biografia de Orta, surgiu assim, neste grupo de textos preliminares como um fecho adequado.

Mas Garcia de Orta deu a este licenciado renovado destaque antes de encerrar o livro. Referimo-nos a uma epístola que o médico valenciano dirigiu ao seu antigo mestre de Coimbra: Tomás Rodrigues da Veiga (1513-1579). Natural de Évora, onde aprendeu as primeiras letras, fez os seus estudos médicos em Salamanca. O físico foi autor de comentários a Galeno e de outros textos eruditos. ${ }^{90}$ Homem da confiança de D. João III, a quem este se referia como "meu médico", foi transferido, em 1540, de Lisboa para a Universidade de Coimbra. Durante a sua permanência nesta Universidade, o seu salário foi sucessivas vezes aumentado por alvarás do Rei. Ordenado Cavaleiro da Ordem de Santiago em 1558, teve como testemunhas o então físico-mor do Reino, o Doutor Diogo Lopes (Cavaleiro da Ordem de Santiago) e o Doutor Diogo de Santiago (Cavaleiro da Ordem de Avis). ${ }^{91}$ Era, assim, um médico bem cotado na corte de

87 Jaime WALter, "Dimas Bosque e as sereias", op. cit., pp. 260-271.

88 Garcia de ORTA, Colóquios dos Simples, op. cit., vol. 2, p. 164.

89 Garcia de OrTA, Colóquios dos Simples, op. cit., vol. 2, p. 186.

90 Commentaria in Galenum, quibus complectitur interpretatio trium librorum Arti Medicae, (Antuérpia, 1564); Commentariorum in Claudii Galeni Opera, medicorum principis complectens interpretationem Artis Medicae, (Antuérpia, 1566) e Commentarij in libros Claud. Galeni duos De febrium differentiis (Coimbra, 1578).

91 Francis Dutra, "The practice of Medicine in Early Modern Portugal. The role and social status of the Fisico-mor and Surgião-mor", in Israel Katz (ed.), Libraries, History and Diplomacy and the Performing Arts. New York, Pendragon Press, 1991, pp. 143-145. 
D. João III e também na de D. Catarina. Sem dúvida um interlocutor atento das palavras de Dimas Bosque e um leitor interessado em Colóquios dos Simples. ${ }^{92}$

A seu respeito escreveu Rocha de Brito:

O Padre António Vieira num dos seus sermóes chama-lhe mesmo Grande Magnus Thomas - . [...] O remoto colega não fora apenas, à maneira de tantos mestres universitários de antanho, um teorisante, um repetidor de Hipócrates e Galeno, ou um comentador mais ou menos arguto e original dos autores gregos e árabes, mas espírito prático e ávido de saber, entretinha as horas de ócio, que lhe deixavam a clínica e o professorado, colhendo pelas colinas e campos do Mondego ervas e arbustos, que ia replantar nos seus hortos para os estudar in visu. ${ }^{33}$

A epístola latina redigida por Dimas Bosque — "Praestantissimo doctori Tomae Roderico in conimbricensi academia medicorum primo Dymas bosque medicus valentius. S.P.D.” encontra-se no final da obra, imediatamente antes da Errata. ${ }^{94}$ Nela, o médico, começou por enumerar os autores clássicos que tinham descrito a origem e virtudes das plantas. No entanto, como sublinhou o licenciado, Tomás da Veiga privilegiava um método de análise do mundo natural inovador. Dimas parecia seguro em relação à eficácia da dedicatória da obra de Orta a tão ilustre personalidade. Ciente da vasta teia de relaçôes na qual Tomás Rodrigues se inseria e que poderia assegurar a divulgação dos Colóquios na Europa, escreveu:

quando encontrei neste país o Doutor Garcia de Orta, [...] logo o aconselhei a que o colocasse [o Tratado sobre os Simples] sob a tua égide, como uma das mais

92 Para mais detalhes biográficos sobre o médico e a sua família vide Francisco Leitão FerReIRA, Notícias cronológicas da Universidade de Coimbra, [...]. Coimbra, Por ordem da Universidade, 1938, vol. 1, pp. 715-726 e Maximiliano Lemos, História da Medicina em Portugal: doutrinas e instituições. Lisboa, Dom Quixote/Ordem dos Médicos, 1991, vol. 1, pp. 250-252. Sobre a rede de relações familiares, científicas e comerciais que este físico mantinha na Europa vide António M. L. ANDRADE, O Cato Minor de Diogo Pires e a poesia didáctica do século xvı. Lisboa, Imprensa Nacional-Casa da Moeda, 2014, pp. 319-333 e Hans PoHL, Die Portugiesen in Antwerpen: (1567-1648). Wiesbaden, Franz Steiner, 1977, pp. 356-360.

93 Rocha de BRITo, "O Doutor Tomás Rodrigues da Veiga, ilustre ervanário", op. cit., pp. 408-409. Esta curta notícia parece-nos suficiente para justificar a oportunidade da Carta que Dimas Bosque dirigiu ao ilustre médico. Sobre o físico ver ainda: Francis DUTRA, "The practice of Medicine in Early Modern Portugal", op. cit., pp. 135-169.

94 Garcia de Orta incluiu este documento no final da obra, após o Colóquio 58. ․ Na sua edição, o Conde de Ficalho optou por colocar este texto no início do livro, imediatamente após a Carta ao leitor redigida por Dimas Bosque. Dado que a posição relativa dos diferentes paratextos dentro da obra nos parece ser relevante, pensamos que esta decisão de Ficalho não favorece a compreensão global do significado dos documentos. Por isso, optamos por nos referir ao texto incluído por Garcia de Orta no final da sua obra. Garcia de OrTA, Colóquios dos Simples, [1563], 1963, fl. 227 f. 
doutas, o que ele fez com o maior agrado. Bem sabia ele, venerando ancião, que és hoje na Europa, o patrono de todos os médicos e como és generoso para todos os estudiosos [...] Oxalá, portanto, sapientíssimo Doutor, que o livro, assim protegido pelo teu escudo e amparado na autoridade do teu nome, ouse caminhar sem medo dos zoilos, entre os sábios, e triunfe em todas as academias da Europa e deste modo possa a juventude colher os frutos e empregar os simples da Índia, pintados com as cores da virtude médica. ${ }^{95}$

Estrategicamente colocada ao lado da referida Errata, esta epístola latina aproximava o projecto científico de Orta da rota das redes eruditas europeias.

Um epigrama surgiu ainda nos Colóquios dos Simples logo a seguir a esta epístola. Trata-se de "Ad Gartiam ab horto medicum apud Indos...”, um curto epigrama redigido por Tomé Caiado. ${ }^{96}$ Sobre este latinista encontrámos muito pouca informação. Como escreveu Rui Manuel Loureiro,

Entre os eruditos portugueses que residiram na Índia durante o século Xvi, contase também Tomé Dias Caiado, que, em 1542, era incumbido de ensinar latim na Sé de Goa. Viveu ainda longos anos naquela cidade, onde proferiu várias orações solenes: em 1547, em honra de D. João de Castro, recém-chegado do cerco de Diu; em finais de 1557 ou princípios do ano seguinte, a propósito da morte de el-rei D. João III; e em 1564, à chegada de D. Antão de Noronha à capital do estado da Índia.

Sobre a sapiência do literato concluiu: "Em todas as oraçôes referidas revelava alguma erudição clássica, citando nomeadamente Homero, Plínio, Cícero e Santo Ambrósio.”97

Foi assim este letrado, a quem competia exaltar os feitos dos portugueses nomeados a desempenhar nobres funçôes no Oriente, que dirigiu um sonoro aplauso a Garcia de Orta. A redacção em latim tornava o seu louvor acessível a toda a comunidade erudita. Deste modo, o pequeno epigrama cantado por este cronista das elites deu visibilidade e crédito ao trabalho de Orta. O seu conteúdo laudatório, assegurou aos leitores mais cépticos o inegável valor da obra que tinham entre mãos. Tal como o privilégio do Vice-Rei e a Carta a Martim Afonso

95 A epístola redigida em latim foi publicada por Rocha de BRITO, "O Doutor Tomás Rodrigues da Veiga, ilustre ervanário", op. cit., pp. 408-409.

96 O epigrama foi vertido para português por Maria Helena Rocha PEREIRA, "Louvores latinos aos 'Colóquios dos Simples e Drogas". Porto, Centro de Estudos Humanísticos, Faculdade de Medicina do Porto, 1963. pp. 1-11. Para consultar o texto latino, ver Garcia de ORTA, Colóquios dos Simples, [1563], 1963. fl. 228 v.

97 Rui Manuel Loureiro, A biblioteca de Diogo do Couto, op. cit., p. 40. 
de Sousa garantiam aos ibéricos a credibilidade das notícias veiculadas nos Colóquios, estes textos finais, engastados entre o Colóquio 58. e a Errata, asseguravam aos letrados europeus a excelência das investigaçóes alcançadas pelo médico.

\section{NOTAS FINAIS}

Apoiada e protegida pelas cúpulas dirigentes do Estado Português da Índia, autorizada com o selo do Inquisidor, valorizada pelas elites eruditas destacadas no Oriente, a obra publicada em Goa, Colóquios dos Simples e Drogas he Cousas Medicinais da India, convinha aos negócios do império e defendia os interesses dos seus súbditos.

Pela multiplicidade de públicos que servia, não lhe conseguimos identificar um patrono único. Ao inequívoco interesse de D. João III e de D. Catarina em reconhecer o património natural da Ásia, há que aliar a relevância estratégica que estas notícias apresentavam no governo do Reino e do Estado da Índia.

Um nome em particular se destacou ao longo de Colóquios dos Simples: o de Martim Afonso de Sousa. Homem a quem Garcia de Orta ficou a dever a sua oportuna saída de Lisboa, ao serviço de quem, como médico privado, viajou no Oriente e ao lado de quem observou as tradiçóes e saberes locais, surgiu, ao longo da obra, como se de uma peça fundamental se tratasse.

Fidalgo educado e costumado no meio cortesão, desde cedo partilhou espaços e vivências com as elites do Reino. Com o desaparecimento, em 1557, de D. João III e o consequente afastamento do seu parente e protector D. António de Ataíde do meio cortesão; com a resignação, em 1562, de D. Catarina do seu cargo de regente, o nobre perdeu o apoio dos seus mais fortes aliados políticos.

Num momento em que as elites do Reino se preparavam para o esquecer, Colóquios dos Simples, publicado em Goa, em 1563, veio reavivar o seu nome, enaltecer os seus feitos e recordar a sua ligação com uma tradição.

Naquela época de transição de poderes, em que o apoio e investimento no desenvolvimento das ciências incentivado por D. João III arriscava não encontrar continuidade, o contributo de Orta não achava melhor interlocutor no Reino do que o deste seu amigo de longa data.

Ao longo da obra, a imagem de fidalgo de linhagem de Martim Afonso de Sousa saiu reforçada assim como foi valorizado o seu evidente contributo para a aquisição e circulação do novo saber.

Para além deste fidalgo, e apesar de surgir de uma forma mais discreta, também o nome de D. Constantino de Bragança, o Vice-rei cessante, que regressou ao Reino em 1561, sobressaiu como sustento do tratado apresentado por Garcia de Orta.

Através de Dimas Bosque, o médico privado de D. Constantino, o percurso de Garcia de Orta tomou forma e foi apresentado ao leitor. As leves correcçóes a aditamentos que Bosque introduziu na obra revelaram o suporte do Vice-Rei ao projecto de Orta. 
Com o apoio das elites, Colóquios dos Simples revelou-se um dos mais inovadores e arrojados contributos da medicina portuguesa para a ciência de Quinhentos.

A afirmação de Portugal enquanto autoridade nas Ciências era, afinal, parte de uma estratégia de afirmação de poder que, desde meados do século XVI, motivava e desafiava os sábios e os governantes portugueses. Naquela segunda metade da centúria, que todos adivinhavam conturbada, importava assinalar e destacar personalidades capazes de sustentar e dar continuidade a tão grandioso projecto.

\section{BIBLIOGRAFIA}

Albuquerque, Luís de, Introdução à história dos descobrimentos. Coimbra, Atlântida, 1962.

Albuquerque, Luís de, Martim Afonso de Sousa. Mem Martins, AlfA, 1989.

Andrade, A. Banha de, Novos mundos do Mundo. Panorama da difusão, pela Europa, de notícias dos Descobrimentos geográficos Portugueses. Lisboa, Junta de Investigaçóes do Ultramar, 1972, 2 vols.

Andrade, A. Banha de, "Drogas do Oriente", Arquivo do Centro Cultural Português 3 (1971), pp. 112-188.

Andrade, António M. L., O Cato Minor de Diogo Pires e a poesia didáctica do século xvi. Lisboa, Imprensa Nacional-Casa da Moeda, 2014.

Anselmo, António, Bibliografia das obras impressas em Portugal no século xvi. Lisboa, Biblioteca Nacional, 1977, [1926].

Barrera, Antonio, Experiencing nature. The Spanish American Empire and the Early Scientific Revolution. Austin, University of Texas Press, 2006.

Biagioli, Mario, Galileo cortesão. Lisboa, Porto Editora, 2003.

Bleichmar, Daniela, Science in the Spanish and Portuguese empires, 1500-1800. Stanford, Stanford University Press, 2009.

Boxer, Charles R., A tentative check-list of Indo-Portuguese imprints. Paris, Centro Cultural Português, 1975, pp. 567-599.

Boxer, Charles R., O Império Colonial Português 1415-1825. Lisboa, Edições 70, 2001.

Braga, Teófilo, A primeira poesia impressa de Luis de Camóes. Lisboa, Adolfo Modesto, 1867.

Buescu, Ana Isabel, D. João III, 1502-1557. Rio de Mouro, Temas e Debates, 2008.

Burke, Peter, A social history of knowledge. From Gutemberg to Diderot. Cambridge, Polity Press, 2008.

Calado, Adelino Almeida, (ed.), "Livro que trata das cousas da Índia e do Japão", Boletim da Biblioteca da Universidade de Coimbra, Vol. XXIV, pp. 1-138.

Cañizares-Esguerra, Jorge, "Iberian Science in Renaissance: ignored how much longer?”, Perspectives on Science 12, n. 1 (2004), pp. 86-124.

Carvalho, Augusto da Silva, "Garcia d’Orta", Revista da Universidade de Coimbra 12 (1934), pp. 61-246.

Carvalho, Joaquim Teixeira de, Homens de outros tempos. Coimbra, Imprensa da Universidade, 1924. 
Carvalho, Teresa Nobre de, "A apropriação de Colóquios dos Simples por dois médicos ibéricos de Quinhentos", in Palmira Fontes da Costa e Adelino Cardoso (orgs.), Percursos na história do livro médico (1450-1800). Lisboa, Edições Colibri, 2011, pp. 59-72

Carvalho, Teresa Nobre de, "Invisible travelers and virtual tracks: knowledge construction in Colóquios dos Simples e Drogas da India of Garcia de Orta (Goa, 1563)”, in Antoni Roca-Rosell (ed.), Proceedings of the 4th ESHS Conference. Barcelona, 2010, pp. 288-293.

Carvalho, Teresa Nobre de, "Os enigmas de uma edição goesa: Colóquios dos Simples de Garcia de Orta", in H. Leitão; L. Giurgevitch; T. N. de Carvalho (eds.), O livro cientifico lido de perto. Lisboa, BNP, 2015 (aceite para publicação).

Carvalho, Teresa Nobre de, O mundo natural asiático aos olhos do Ocidente. Contribuição dos textos ibéricos quinhentistas para a construção de uma nova consciência europeia sobre a Ásia. Lisboa, UL, 2012 (dissertação de doutoramento - texto policopiado).

Clusius, Carolus, Aromatum et simplicium. Antuérpia, Plantin, 1567.

Correia, Gaspar, Lendas da India, Rodrigo de Lima Felner (ed.). Lisboa, 1864.

Costa, Cristóvão da, Tractado de las drogas. Burgos, Martin de Victoria, 1578.

Costa, Palmira Fontes da; Carvalho, Teresa Nobre de, "Between East and West: Garcia de Orta's Colloquies and the circulation of medical knowledge in the sixteenth century", Asclepio, Revista de Historia de la Medicina y de la Ciencia 65, 1 (enero-junio 2013), pp. 1-13.

Cunha, José Gerson da, The origins of Bombay. Bombay, Society’s Library, Town Hall, 1900.

Dias, José S. Silva, A política cultural da época de D. João III. Coimbra, Universidade de Coimbra, 1969, 2 vols.

Ditos portugueses dignos de memória. História íntima do século Xvi anotada e comentada por José Hermano Saraiva. Póvoa do Varzim, Publicaçóes Europa-América, 1980.

Domingues, Francisco Contente, Os navios do mar oceano. Teoria e empiria na arquitectura naval portuguesa dos séculos XVI e Xvir. Lisboa, CHUL, 2004.

Dutra, Francis, "The practice of Medicine in Early Modern Portugal. The role and social status of the Fisico-mor and Surgiāo-mor", in Israel Katz (ed.), Libraries, History and Diplomacy and the Performing Arts. New York, Pendragon Press, 1991, pp. 143-145.

Egmond, Florike, The world of Carolus Clusius: Natural History in the making: 1550-1610. Londres, Pickering \& Chatto, 2010.

Ferrâo, José Mendes, A aventura das plantas e os descobrimentos. Lisboa, Chaves Ferreira, 2005.

Ferreira, Francisco Leitão, Notícias cronológicas da Universidade de Coimbra, [...], Primeira edição publicada, revista e anotada por Joaquim de Carvalho. Coimbra, Por ordem da Universidade, 1938-1956, 3 volumes.

Ficalho, Conde de, Garcia de Orta e o seu tempo. Lisboa, Imprensa Nacional, 1886.

Fonseca, José Tello da, História da farmácia Portuguesa através da Legislação. Porto, Empresa Industrial Gráfica do Porto, 1935, 2 volumes.

Fragoso, Juan, Discurso de las cosas aromáticas. Madrid, Francisco Sanchez, 1572.

GÂndavo, Pêro Magalhães, História da Provincia de Santa Cruz. Lisboa, Antonio Gonsalvez, 1576. 
Goodman, David, Power and Penury: Government, technology and science in Philip II's Spain. Cambridge, Cambridge University Press, 1988.

Gschwend, Annemarie Jordan, "Catarina de Áustria: Colecção e Kunstkammer de uma princesa renascentista”, Oceanos 16 (1992), pp. 62-70.

Gschwend, Annemarie Jordan, "Marvels of the East. Renaissance curiosity collections in Portugal» in Nuno Vassallo e SiLva (coord.), A herança de Rauluchantim. Lisboa, 1996, pp. 82-127.

Hooykaas, Reijer, "Science in manueline style. The historical context of D. João de Castro's Works", in Armando Cortesáo; Luís de Albuquerque, Obras Completas de D. João de Castro. Coimbra, Academia Internacional da Cultura Portuguesa, 1981, vol. IV, pp. 231-426.

Jordan, Annemarie, A rainha colecionadora. Catarina de Áustria. Maia, Círculo de Leitores, 2012.

Jorge, Ricardo, La médecine et les médecins dans l'éxpansion mondiale des Portugais. Lisboa, Tip. Seara Nova, 1935.

Leitão, Henrique, “Um mundo novo e uma nova ciência”, in Henrique Leitão (ed.), $360^{\circ}$ Ciência Descoberta. Lisboa, Fundação Calouste Gulbenkian, 2013, pp. 15-40.

Lemos, Maximiliano História da Medicina em Portugal: doutrinas e instituiçōes. Lisboa, Publicações Dom Quixote/Ordem dos Médicos, 1991, 2 volumes.

López-Piñero, José-Maria, (dir.), Historia de la ciência y de la técnica en la corona de Castilla, Vol. III. Siglos Xvi y Xvir. Salamanca, Junta de Castilla y Léon, Consejeria de Educación y Cultura, 2002.

Loureiro, Rui Manuel, “Garcia de Orta e os Colóquios dos Simples: Observaçóes de um viajante sedentário”, in Anabela Mendes e Gabriela Fragoso (org.), Garcia de Horta e Alexandre von Humboldt. Errâncias, Investigaçôes e Diálogos entre Culturas. Lisboa, Universidade Católica Editora, 2008, pp. 135-145.

Loureiro, Rui Manuel, Animais Orientais: Fauna exótica dos descobrimentos. Lagos, Câmara Municipal de Lagos, 2008.

Matos, Manuel Cadafaz de, "Humanismo e evangelização no Oriente no século xvi", Revista ICALP, no 7-8 (1987), pp. 41-72.

Mundy, Barbara, The mapping of New Spain: indigenous cartography and the maps of the Relaciones Geograficas. Chicago, Chicago University of Chicago Press, 2000.

Orta, Garcia de, Colóquios dos Simples e Drogas da Índia, Edição fac-similada da dirigida e anotada pelo Conde de Ficalho. Lisboa, Imprensa Nacional, 1987 [1891-1895], 2 volumes.

Orta, Garcia de, Colóquios dos Simples, edição fac-similada da edição princeps. Lisboa, Academia das Ciências de Lisboa, 1963, [1563].

Pearson, Michael, "Hindu medical practices in Sixteenth-Century Western India: Evidence from Portuguese sources”, Portuguese Studies 17 (2001), pp. 100-113.

Pelúcia, Alexandra, Martim Afonso de Sousa e a sua Linhagem: Trajectórias de uma elite no Império de D. João III e D. Sebastião. Lisboa, CHAM, 2009.

Pereira, Maria Helena Rocha, "Louvores latinos aos 'Colóquios dos Simples e Drogas". Porto, Centro de Estudos Humanísticos, Faculdade de Medicina do Porto, 1963, pp. 1-11. 
Pina, Luís de, "As ciências na história do Império colonial português (séculos XV-XIX)" Extracto dos tomos dos anos 1937 a 1945 nos Anais da Faculdade de Ciências do Porto. Porto, Imprensa Portuguesa, 1945.

Pina, Luís de, "Garcia de Orta e o Magistério Universitário de Filosofia Natural em Lisboa", O Médico, vol. 636 (1963), pp. 3-26.

Pohl, Hans, Die Portugiesen in Antwerpen: (1567-1648). Wiesbaden, Franz Steiner, 1977.

Portuondo, Maria, Secret Science. Spanish cosmography and the New World. Chicago, The University of Chicago Press, 2009.

Puga, Rogério Manuel, “Os elementos paratextuais dos Colóquios de Garcia de Orta”, in: Anabela Mendes e Gabriela Fragoso (org.), Garcia de Horta e Alexandre von Humboldt. Errâncias, Investigaçôes e Diálogos entre Culturas. Lisboa, Universidade Católica Editora, 2008, pp. 119-134.

Ribeiro, Aquilino, Constantino de Bragança VII Vizo-Rei da Índia. Venda Nova, Bertrand Editora, 1987,

Sánchez-Martínez, Antonio, “Ciencia ibérica y el mundo Atlántico”, Dynamis 31 (2011), pp. 245-269.

SÁnchez-Martínez, Antonio, "La voz de los artesanos en el Renacimiento científico: cosmógrafos y cartógrafos en el preludio de la "nueva filosofía natural”, Arbor, CLXXXVI, 743 (Maio-Junho 2010), pp. 449-460.

SAntos, Catarina Madeira, "Goa é a chave de toda a Índia”, Perfil político da capital do Estado da Índia (1505-1570). Lisboa, CNCDP, 1999.

Schiebinger, Londa; Swan, Claudia, Colonial Botany. Science, Commerce and Politics in Early Modern Europe. Philadelphia, University of Pennsylvania Press, 2007.

Scholdberg, H., Bibliography of Goa and the Portuguese India. New Delhi, 1982.

Silva, Mário Justino, O rei e os nobres: imagens do quotidiano nos ditos portugueses dignos de memória (século xvi). Cascais, Patrimonia, 2004.

VeIga, Tomás Rodrigues da, Commentaria in Galenum, quibus complectitur interpretatio trium librorum Arti Medicae. Antuérpia, Plantin, 1564.

Veiga, Tomás Rodrigues da, Commentarij in libros Claud. Galeni duos De febrium differentiis. Coimbra, I. Barrerium, 1578.

VeIga, Tomás Rodrigues da, Commentariorum in Claudii Galeni Opera, medicorum principis complectens interpretationem Artis Medicae. Antuérpia, Plantin, 1566.

VesÁlio, André, De humani corporis fabrica libri septem. Basileia, ex of. J. Oporini, 1543.

Walter, Jaime, "Dimas Bosque e as sereias", Studia 12 (1963), pp. 260-271.

Walter, Jaime, "Simão Álvares e o seu rol das drogas da Índia”, Studia 10 (1962), pp. 117-149.

Županov, Ines, "Drugs, health, bodies and souls in the Tropics. Medical Experiments in Sixteenth century Portuguese India”, The Indian Economic and Social History Review 39, 1 (2002), pp. 1-43. 
A partir dos alvores do século XVI, a matéria médica torna-se indiscutivelmente um tema de primeira grandeza entre os membros da República das Letras, objecto de estudo e de controvérsia entre os mais notáveis humanistas europeus, em particular entre os cultores da arte médica. Entre os autores em destaque neste volume encontram-se, à cabeça, os nomes de Amato Lusitano, Garcia de Orta e Nicolás Monardes, famosos pelos contributos valiosos que deram para o conhecimento do mundo natural. 0 volume encontra-se dividido em duas partes: a primeira, subordinada ao título "Humanismo e Ciência", alberga os estudos que versam sobre todos os autores estudados, à excepção de Amato Lusitano; a segunda está reservada a um conjunto de trabalhos dedicados exclusivamente ao médico albicastrense, cuja autoria se fica a dever, em boa parte, aos membros da equipa do projecto de I\&D "Dioscórides e o Humanismo Português: os Comentários de Amato Lusitano", tomando, por isso, 0 seu próprio título. Nesta segunda parte, oferece-se, desde já, aos leitores uma amostra significativa do trabalho desenvolvido no âmbito do projecto e que culminará, assim se espera, na edição e tradução integral para língua portuguesa das quatro obras previstas de Dioscórides, Amato Lusitano e Pietro Andrea Mattioli. 
